\title{
Theta-Frequency Bursting and Resonance in Cerebellar Granule Cells: Experimental Evidence and Modeling of a Slow $\mathrm{K}^{+}-$ Dependent Mechanism
}

\author{
Egidio D’Angelo,, ${ }^{1,2}$ Thierry Nieus, ${ }^{1}$ Arianna Maffei, ${ }^{1}$ Simona Armano ${ }^{1}$ Paola Rossi, ${ }^{1}$ Vanni Taglietti, ${ }^{1}$ \\ Andrea Fontana, ${ }^{3}$ and Giovanni $\mathrm{Naldi}^{4}$ \\ ${ }^{1}$ Department of Molecular/Cellular Physiology and Instituto Nazionale per la Fisica della Materia, University of Pavia, \\ I-27100 Pavia, Italy, ${ }^{2}$ Department of Evolutionary and Functional Biology, University of Parma, Parma, Italy, ${ }^{3}$ Department \\ of Nuclear and Theoretical Physics, University of Pavia, Pavia, Italy, and ${ }^{4}$ Department of Mathematics and Applications, \\ University of Milano Bicocca, Milan, Italy
}

Neurons process information in a highly nonlinear manner, generating oscillations, bursting, and resonance, enhancing responsiveness at preferential frequencies. It has been proposed that slow repolarizing currents could be responsible for both oscillation/burst termination and for high-pass filtering that causes resonance (Hutcheon and Yarom, 2000). However, different mechanisms, including electrotonic effects (Mainen and Sejinowski, 1996), the expression of resurgent currents (Raman and Bean, 1997), and network feedback, may also be important. In this study we report theta-frequency $(3-12 \mathrm{~Hz})$ bursting and resonance in rat cerebellar granule cells and show that these neurons express a previously unidentified slow re- polarizing $\mathrm{K}^{+}$current $\left(I_{\mathrm{K} \text {-slow }}\right)$. Our experimental and modeling results indicate that $I_{\mathrm{K} \text {-slow }}$ was necessary for both bursting and resonance. A persistent (and potentially a resurgent) $\mathrm{Na}^{+}$current exerted complex amplifying actions on bursting and resonance, whereas electrotonic effects were excluded by the compact structure of the granule cell. Theta-frequency bursting and resonance in granule cells may play an important role in determining synchronization, rhythmicity, and learning in the cerebellum.

Key words: bursting; resonance; M-current; cerebellum; granule cell; modeling
Neurons process information by generating action potentials organized either in regular discharges (fast repetitive firing) or in bursts (Connors and Gutnik, 1990), which can occur repetitively when they are sustained by slow membrane potential oscillations (Wang and Rinzel, 1999). Moreover, some neurons respond better to a preferential input frequency, a property called resonance (Hutcheon and Yarom, 2000). Oscillations, bursting, and resonance have been related to synchronization of neuronal activity and to the emergence of brain rhythms (Llinas, 1988).

Oscillations and bursting can arise from various mechanisms that involve slow depolarizing and repolarizing currents. Noteworthy examples are provided by the interaction of a persistent $\mathrm{Na}^{+}$current $\left(I_{\mathrm{Na}-\mathrm{p}}\right)$ with a slow $\mathrm{K}^{+}$current $\left(I_{\mathrm{M}}\right)$ in hippocampal pyramidal neurons (Gutfreund et al., 1995; Pape and Driesang, $1998)$ or with an inward rectifier current $\left(I_{\mathrm{h}}\right)$ in entorhinal neurons (Alonso and Llinas, 1989; Dickson et al., 2000). In thalamic neurons, depolarization and delayed repolarization are determined by low-threshold $\mathrm{Ca}^{2+}$ current $\left(I_{\mathrm{T}}\right)$ activation and inactivation and are regulated by other currents, including $I_{\mathrm{h}}(\mathrm{McCor}-$ mick and Huguenard, 1992). In invertebrate cells, $\mathrm{Ca}^{2+}$ dependent bursts are terminated by a $\mathrm{Ca}^{2+}$-dependent $\mathrm{K}^{+}$ current $\left(I_{\mathrm{AHP}}\right)$ (Wang and Rinzel, 1999). In addition, bursting

\footnotetext{
Received Aug. 10, 2000; revised Oct. 30, 2000; accepted Nov. 3, 2000.

This work was supported by European Community Grants PL97 0182 and PL97 6060, and by Instituto Nazionale per la Fisica della Materia. We acknowledge Marja-Leena Linne and Massimiliano Zaniboni for contributing to preliminary simulations, and Lia Forti and Elisabetta Sola for their helpful comments on this manuscript.

Correspondence should be addressed to Egidio D'Angelo, Department of Cellular/Molecular Physiology and Pharmacology, Via Forlanini 6, I-27100 Pavia, Italy. E-mail: dangelo@unipv.it.

Copyright (C) 2001 Society for Neuroscience $\quad 0270-6474 / 01 / 210759-12 \$ 15.00 / 0$
}

emerges when a membrane potential difference is established between dendrites and soma, causing rebound depolarization after a spike (Mainen and Sejinowski, 1996). Rebound depolarization may also be caused by currents activated by spike repolarization, e.g., by a resurgent $\mathrm{Na}^{+}$current (Raman and Bean, 1997). Despite the multitude of mechanisms that potentially generate oscillation and bursting, resonance essentially requires a slow repolarizing current that reduces neuronal excitability at low input frequency (Hutcheon et al., 1996a,b; Hutcheon and Yarom, 2000).

The most apparent discharge mode of cerebellar granule cells is fast repetitive firing (Gabbiani et al., 1994; D'Angelo et al., 1995). However, a more complex electrical behavior has been suggested by the observation of spike bursting unveiled by pharmacological manipulation (D'Angelo et al., 1998). In this study, we report that cerebellar granule cells also show thetafrequency resonance, and we suggest that both bursting and resonance are based on a slow $\mathrm{K}^{+}$current. This conclusion is supported by a mathematical model that provides a realistic reconstruction of granule cell electroresponsiveness.

Theta-frequency bursting and resonance in granule cells may play an important role in determining synchronization (Maex and DeShutter, 1998), rhythmicity (Pellerin and Lamarre, 1997; Hartmann and Bower, 1998), and learning (D'Angelo et al., 1999; Armano et al., 2000) at the major input stage of the cerebellum.

\section{MATERIALS AND METHODS}

Whole-cell patch-clamp recordings. Cerebellar granule cells were recorded in acute cerebellar slices obtained from $20 \pm 2$-d-old rats. Slice preparation and patch-clamp recordings were performed as reported previously (Rossi et al., 1994, 1998; D’Angelo et al., 1995, 1997, 1998, 1999; Armano et al., 2000). 
Current-clamp recordings were performed at $30^{\circ} \mathrm{C}$. The extracellular solution contained (in mM): $\mathrm{NaCl} 120, \mathrm{KCl} 2, \mathrm{MgSO}_{4} 1.2, \mathrm{NaHCO}_{3} 26$, $\mathrm{KH}_{2} \mathrm{PO}_{4} 1.2, \mathrm{CaCl}_{2}$, glucose 11 , and bicuculline 0.01 , and was equilibrated with $95 \% \mathrm{O}_{2}$ and $5 \% \mathrm{CO}_{2}, \mathrm{pH}$ 7.4. The pipette solution contained (in mM): K-gluconate 126 (or $\mathrm{Cs}_{2} \mathrm{SO}_{4} 78$ ), $\mathrm{KCl} 4$ (or $\mathrm{CsCl} 4$ ), $\mathrm{NaCl} 4$, $\mathrm{MgSO}_{4} 1, \mathrm{CaCl}_{2}$ 0.02, BAPTA 0.1, glucose 15, ATP 3, GTP 0.1, HEPES 5; $\mathrm{pH}$ was adjusted to 7.2 with $\mathrm{KOH}$ (or $\mathrm{CsOH}$ ).

Voltage-clamp recordings were performed at room temperature $\left(25.5^{\circ} \mathrm{C}\right)$. The extracellular solution contained (in $\mathrm{mM}$ ): $\mathrm{NaCl} 100, \mathrm{KCl} 2$, $\mathrm{KH}_{2} \mathrm{PO}_{4} 1.2, \mathrm{MgSO}_{4} 1.2, \mathrm{NaHCO}_{3} 26$, glucose 11, Tetraethyl-ammonium $\mathrm{Cl}^{-}$(TEA) 20, 4-amino-piridine (4-AP) $4, \mathrm{Ni}^{2+}$ 2, tetrodotoxin (TTX) 0.001 , and bicuculline 0.01 , and was equilibrated with $95 \% \mathrm{O}_{2}$ and $5 \%$ $\mathrm{CO}_{2}, \mathrm{pH}$ 7.4. The pipette solution contained (in mM): K-gluconate 126, $\mathrm{NaCl} 4, \mathrm{MgSO}_{4} 1, \mathrm{CaCl}_{2}$ 0.02, BAPTA 0.1, glucose 15, ATP 3, GTP 0.1, HEPES 5; pH was adjusted to 7.2 with $\mathrm{KOH}$.

TEA, 4-AP, TTX, and bicuculline were obtained from Sigma (St. Louis, MO). The glutamate receptor antagonists D-2-amino-5phosphonovaleric acid (APV), 7-chlorokinurenic acid (7-Cl-Kyn), and 6-cyano-7-nitroquinoxaline-2,3-dione (CNQX) were obtained from Tocris Cookson (Bristol, UK).

Data were recorded with an Axopatch 200B amplifier, digitized with a Digidata 1200 interface $(500 \mu \mathrm{sec} /$ point $)$, and analyzed with PClamp software (Axon Instruments, Foster City, CA). In voltage-clamp recordings, leak subtraction was performed by using a $\mathrm{P} / 4$ protocol. All data are reported as mean $\pm \mathrm{SD}$.

Mathematical modeling. A mathematical model of rat cerebellar granule cell electroresponsiveness (D’Angelo et al., 1995, 1998; Brickley et al., 1996) was constructed using the NEURON simulator (Hines and Carnevale, 1997). Because granule cells have a compact electrotonic structure (Silver et al., 1992; D'Angelo et al., 1993, 1995), a singlecompartment model was used. The experimental value of membrane capacitance ( $3 \mathrm{pF}$; see refences above) was used to calculate the granule cell surface, assuming a spherical shape and a specific membrane capacitance of $1 \mu \mathrm{F} / \mathrm{cm}^{2}$.

Mathematical methods. The mathematical problem in neuronal simulation is to solve the set of differential equations representing membrane voltage, intracellular $\mathrm{Ca}^{2+}$ concentration, and channel gating dynamics [see for example Yamada et al. (1998)]. Voltage was obtained as the time integral of the equation:

$$
d V / d t=-1 / C_{\mathrm{m}} *\left\{\Sigma\left[g_{\mathrm{i}}^{*}\left(V-V_{\mathrm{i}}\right)\right]+\mathrm{i}_{\mathrm{inj}}\right\},
$$

where $V$ is membrane potential, $C_{\mathrm{m}}$ is membrane capacitance, $g_{\mathrm{i}}$ is ionic conductance, $V_{\mathrm{i}}$ is reversal potential (the subscript $\mathrm{i}$ indicates different channels), and $i_{\text {inj }}$ is the injected current. Membrane conductances were represented using Hodgkin-Huxley-like models (Hodgkin and Huxley, 1952) of the type:

$$
g_{\mathrm{i}}=G_{\max _{\mathrm{i}}} * x_{\mathrm{i}}^{\mathrm{zi}} * y_{\mathrm{i}}
$$

where $G_{\text {max }_{\mathrm{i}}}$ is the maximum ionic conductance, $x_{\mathrm{i}}$ and $y_{\mathrm{i}}$ are state variables (probabilities ranging from 0 to 1 ) for a gating particle, and $z_{\mathrm{i}}$ is the number of such gating particles in ionic channel i. $x$ and $y$ (with the suffix i omitted) were related to the first-order rate constants $\alpha$ and $\beta$ by the equations:

$$
\begin{array}{cc}
x_{\infty}=\alpha_{\mathrm{x}} /\left(\alpha_{\mathrm{x}}+\beta_{\mathrm{x}}\right) & y_{\infty}=\alpha_{\mathrm{y}} /\left(\alpha_{\mathrm{y}}+\beta_{\mathrm{y}}\right), \\
\tau_{\mathrm{x}}=1 /\left(\alpha_{\mathrm{x}}+\beta_{\mathrm{x}}\right) & \tau_{\mathrm{y}}=1 /\left(\alpha_{\mathrm{y}}+\beta_{\mathrm{y}}\right),
\end{array}
$$

where $\alpha$ and $\beta$ are functions of voltage. The equations used to parameterize $\alpha$ and $\beta$ and the state variables $x_{\infty}, \tau_{\mathrm{x}}, y_{\infty}$, and $\tau_{\mathrm{y}}$ for different ionic channels are shown in Table 1 . The state variable kinetics were:

$$
\begin{aligned}
& d x / d t=\left(x_{\infty}-x\right) / \tau_{\mathrm{x}}, \\
& d y / d t=\left(y_{\infty}-y\right) / \tau_{\mathrm{y}} .
\end{aligned}
$$

The model included a leakage current and voltage-dependent $\mathrm{Na}^{+}$, $\mathrm{Ca}^{2+}$, and $\mathrm{K}^{+}$conductances (see Table 1 ). Nernst equilibrium potentials were calculated from ionic concentrations used in current-clamp recordings. The $\mathrm{Ca}^{2+}$ equilibrium potential was updated after changes in the intracellular $\mathrm{Ca}^{2+}$ concentration.

All ionic currents used in the model have been identified in cerebellar granule cells in situ, when the excitable response has assumed its mature pattern (>P20) (D'Angelo et al., 1997). Gating kinetics were corrected using a $Q_{10}=3$ according to the relation $Q_{10}{ }^{\text {(Tsim-Texp)/10 }}$ (Gutfreund
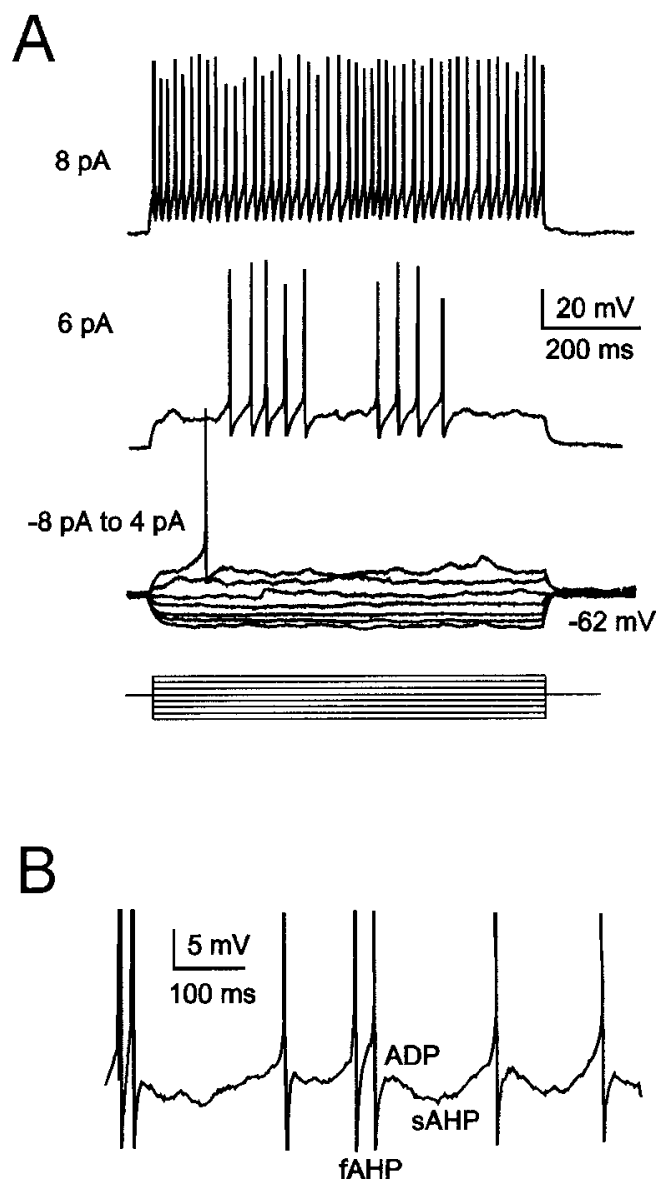

Figure 1. Granule cell electroresponsiveness during step current injection. $A$, The injection of current steps (from -8 to $6 \mathrm{pA}$, resting potential $=-62 \mathrm{mV}$ ) causes inward rectification in the hyperpolarizing direction. Spikes are activated around $-40 \mathrm{mV}$. The tracing at $4 \mathrm{pA}$ shows a single spike, the tracing at $6 \mathrm{pA}$ shows spikes clustered in two bursts, and the tracing at $8 \mathrm{pA}$ shows regular repetitive firing. $B$, Just-threshold response illustrating spike fast afterhyperpolarization ( $f A H P$ ), slow afterhyperpolarization $(s A H P)$, and afterdepolarization $(A D P)$. The neuron in $B$ is different from that in $A$ (spikes are truncated). Recordings in this and the following figures were performed in the presence of $10 \mu \mathrm{M}$ bicuculline.

et al., 1995) to account for differences between simulation temperature $\left(T \operatorname{sim}=30^{\circ} \mathrm{C}\right)$ and experimental temperature $\left(T_{\text {exp }}\right)$. Maximum ionic conductances were corrected for ionic concentration differences between voltage- and current-clamp recordings. A further adjustment (usually $<30 \%$ ) of current densities allowed us to fine tune the excitable response [for further explanations see Traub and Llinas (1979); Traub et al. (1991); Vanier and Bower (1999)].

Leakage current. Mature rat cerebellar granule cells in situ have an aspecific and a GABA-A receptor-dependent leakage (Brickley et al., 1996). In the model, leakage consisted of a $5.68 \times 10^{-5} \mathrm{~S} / \mathrm{cm}^{2}$ conductance with reversal potential at $-59 \mathrm{mV}\left(g_{\mathrm{L}}\right)$, and of a $2.17 \times 10^{-5}$ $\mathrm{S} / \mathrm{cm}^{2} \mathrm{Cl}^{-}$conductance with reversal potential at $-65 \mathrm{mV}$ (accounting for $28 \%$ of the total input conductance) (Armano et al., 2000). No qualitative difference was observed in model responses by setting GABA-A receptor leakage to zero (data not shown).

$\mathrm{Na}{ }^{+}$currents $\left(\mathrm{I}_{N a-f} \mathrm{I}_{N a-p}, \mathrm{I}_{N a-r}\right)$. Mature rat cerebellar granule cells in situ express a fast and persistent $\mathrm{Na}^{+}$current $\left(I_{\mathrm{Na}-\mathrm{f}}\right.$ and $\left.I_{\mathrm{Na}-\mathrm{p}}\right)$ (D'Angelo et al., 1998) and probably also a resurgent $\mathrm{Na}^{+}$current $\left(I_{\mathrm{Na}-}\right)(\mathrm{E}$. D'Angelo and J. Magistretti, unpublished observations). The $I_{\mathrm{Na}-\mathrm{f}}$ model was based on Gutfreund et al. (1995), and inactivation was slowed down around threshold to reproduce spike adaptation during bursts (Mainen et al., 1995). $I_{\mathrm{Na-f}}$ density was set to reproduce repetitive firing. $I_{\mathrm{Na}-\mathrm{p}}$ was reproduced from Gutfreund et al. (1995) and shifted by $-2 \mathrm{mV}$ to match spike threshold. $I_{\mathrm{Na}-\mathrm{p}}$ density $\left(1 / 65 I_{\mathrm{Na}-\mathrm{f}}\right)$ was set to reproduce $\mathrm{Na}^{+}$- 
A

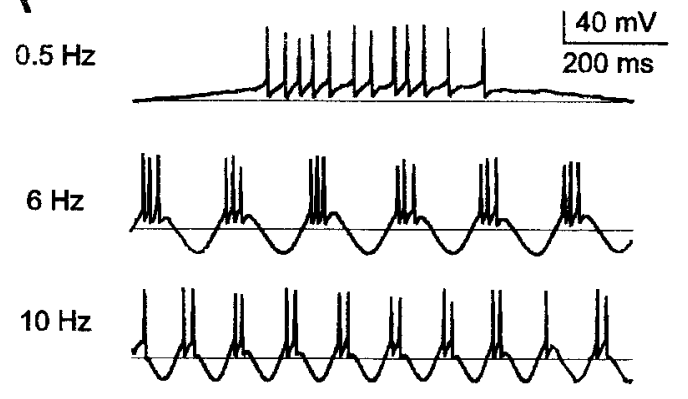

B
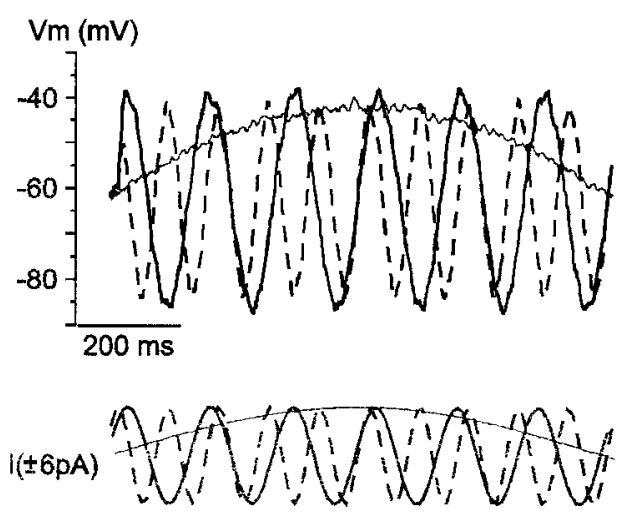
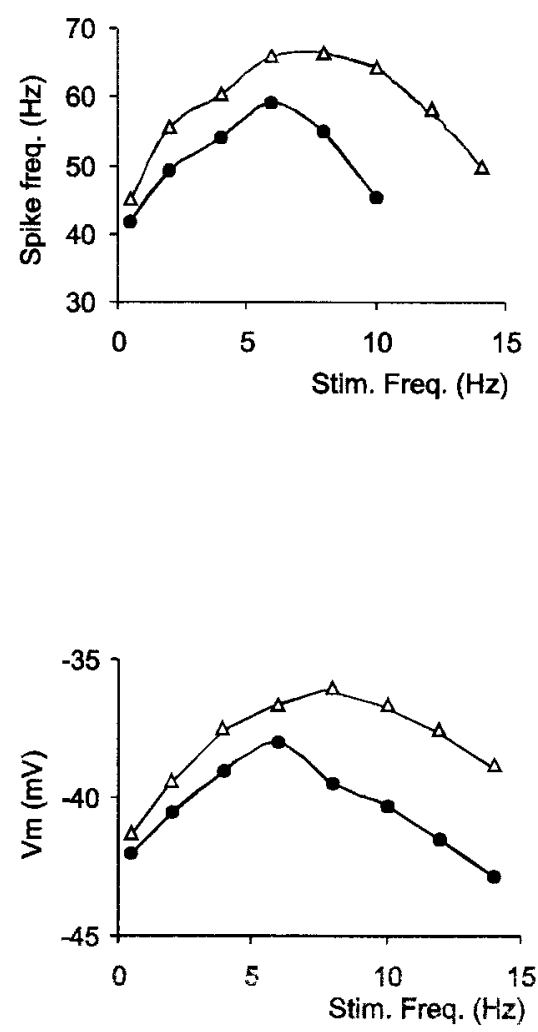

Figure 2. Resonance in a cerebellar granule cell (same cell as in Fig. 1A). $A$, Injection of sinusoidal currents at various frequencies $(0.5-40 \mathrm{~Hz})$ reveals resonance in burst spike frequency, which was measured by dividing the time period between the first and last spike in a burst by the number of interspike intervals. The plot shows that the resonance frequency was $6 \mathrm{~Hz}$, with sinusoidal currents of $\pm 6 \mathrm{pA}(-)$ and $8 \mathrm{~Hz}$ with \pm 8 pA $(\Delta)$. At frequencies higher than those shown in the plot, just one or no spikes were generated, and spike frequency fell to zero. $B$, After $1 \mu \mathrm{M}$ TTX perfusion, injection of sinusoidal currents at various frequencies reveals resonance in the maximum depolarization reached during the positive phase of the sinusoidal voltage response. The plot shows that the resonance frequency was $6 \mathrm{~Hz}$, with sinusoidal currents of $\pm 6 \mathrm{pA}$ $(\bullet)$ and $8 \mathrm{~Hz}$ with $\pm 8 \mathrm{pA}(\Delta)$. Beyond the resonance peak, the sinusoidal voltage response decreased monotonically until $40 \mathrm{~Hz}$ (data not shown). dependent plateaus (D'Angelo et al., 1998). $I_{\mathrm{Na-r}}$ was reconstructed from Raman and Bean (1997). $I_{\mathrm{Na}-\mathrm{r}}$ density (initially $1 / 26 I_{\mathrm{Na}-\mathrm{f}}$ ) was regulated in different simulations.

$\mathrm{Ca}^{2+}$ current $\left(\mathrm{I}_{\mathrm{Ca}}\right)$. The $\mathrm{I}_{\mathrm{Ca}}$ model was derived from high-threshold $\mathrm{Ca}^{2+}$ currents (mostly N-type) measured in mature rat cerebellar granule cells in situ (Rossi et al., 1994). $I_{\mathrm{Ca}}$ had fast second-order activation kinetics and slow voltage-dependent inactivation. $I_{\mathrm{Ca}}$ density was halved to account for different extracellular $\mathrm{Ca}^{2+}$ concentrations.

$K^{+}$currents $\left(\mathrm{I}_{K-V}, \mathrm{I}_{K-C a}, \mathrm{I}_{K-A}, \mathrm{I}_{K-\text { slow, }}, \mathrm{I}_{K-I R}\right)$. Mature rat cerebellar granule cells in situ express $I_{\mathrm{K}-\mathrm{V}}, I_{\mathrm{K}-\mathrm{Ca}}$, and $I_{\mathrm{K}-\mathrm{A}}$ (Cull-Candy et al., 1989; Bardoni and Belluzzi, 1993), $I_{\mathrm{K}-\mathrm{IR}}$ (Rossi et al., 1998), and $I_{\mathrm{K} \text {-slow }}$ (this study). $I_{\mathrm{K}-\mathrm{Y}}$ is a voltage-dependent $\mathrm{K}^{+}$current resembling other neuronal delayed rectifiers, and its model has been adapted from Gutfreund et al. $(1995) . I_{\mathrm{K}-\mathrm{V}}$ was shifted by $-5 \mathrm{mV}$ to match $I_{\mathrm{Na}-\mathrm{f}} . I_{\mathrm{K}-\mathrm{Ca}}$ is a voltageand $\mathrm{Ca}^{2+}$-dependent $\mathrm{K}^{+}$current corresponding to "big-K" channel recordings from granule cells in culture (Fagni et al., 1991), the kinetics of which are largely determined by those of the associated $\mathrm{Ca}^{2+}$ channels and intracellular $\mathrm{Ca}^{2+}$ fluctuations. The $I_{\mathrm{K}-\mathrm{Ca}}$ model is the same as in Gabbiani et al. (1994), and $I_{\mathrm{K}-\mathrm{Ca}}$ density was set close to that of $I_{\mathrm{K}-\mathrm{V}} \cdot I_{\mathrm{A}}$ is a fast-activating, fast-inactivating voltage-dependent $\mathrm{K}^{+}$current, which was reproduced from data reported by Bardoni and Belluzzi (1993). $I_{\mathrm{K} \text {-slow }}$ is a slow $\mathrm{Ca}^{2+}$-independent TEA-insensitive $\mathrm{K}^{+}$current, which was reconstructed from data shown in Figure $5 . I_{\mathrm{K} \text {-slow }}$ voltage dependence was shifted by $-10 \mathrm{mV}(-8 \mathrm{mV}$ accounting for liquidjunction potential and $-2 \mathrm{mV}$ required to maintain a proper matching with $\left.I_{\mathrm{Na}-\mathrm{p}}\right) \cdot I_{\mathrm{K}-\mathrm{IR}}$ is a fast inward rectifier current that was reconstructed from data reported by Rossi et al. (1998).

$\mathrm{Ca}^{2+}$ dynamics. The intracellular $\mathrm{Ca}^{2+}$ concentration, $\left[\mathrm{Ca}^{2+}\right]$, was calculated through the equation:

$$
d\left[\mathrm{Ca}^{2+}\right] / d t=-\mathrm{I}_{\mathrm{Ca}} /\left(2 \mathrm{~F}^{*} \mathrm{Ad}\right)-\left(\beta_{\mathrm{Ca}}\left(\left[\mathrm{Ca}^{2+}\right]-\left[\mathrm{Ca}^{2+}\right]_{0}\right)\right)
$$

where $d$ is the depth of a shell adjacent to the cell surface of area $A, \beta_{\mathrm{Ca}}$ determines the loss of $\mathrm{Ca}^{2+}$ ions from the shell approximating the effect of fluxes, ionic pumps, diffusion, and buffers (Traub and Llinas, 1979; McCormick and Huguenard, 1992; DeSchutter and Smolen, 1998), and $\mathrm{Ca} 0$ is resting $\left[\mathrm{Ca}^{2+}\right]$. Once $I_{\mathrm{Ca}}$ and $I_{\mathrm{KCa}}$ had been set, $\mathrm{Ca}^{2+}$ dynamics were adapted to yield $\mathrm{Ca}^{2+}$ transients of $\sim 1 \mu \mathrm{M}$, similar to those reported by Gabbiani et al. (1994), and to reproduce the excitable response (Traub and Llinas, 1979; Traub et al., 1991). Parameters used in Equation 7 were $d=200 \mathrm{~nm}, \beta_{\mathrm{Ca}}=1.5$, and $\mathrm{Ca} 0=100 \mathrm{~nm}$. $\mathrm{Ca} 0$ was measured in rat cerebellar granule cells in culture (Irving et al., 1992; Marchetti et al., 1995) and experimentally maintained by appropriate BAPTA-Ca ${ }^{2+}$ buffers (see above).

Resting membrane potential. Resting membrane potential in the model settled at $-80 \mathrm{mV}$, reflecting a prominent contribution of $I_{\mathrm{K}-\mathrm{IR}}$. Although resting membrane potential measured in rat cerebellar granule cells ranges from -60 to $-85 \mathrm{mV}$ (D'Angelo et al., 1995, 1998; Brickley et al., 1996; Watkins and Mathie, 1996; Rossi et al., 1998; Armano et al., 2000), at $-80 \mathrm{mV}$ the model was rather insensitive to manipulation of ionic conductances, which provided a useful reference potential for subsequent simulations.

\section{RESULTS}

\section{Bursting and resonance in granule cell}

Intrinsic granule cell electroresponsiveness was investigated in current-clamp recordings. During step current injection (Fig. $1 A$ ), granule cells showed inward rectification in the hyperpolarizing direction. Just-threshold depolarizing currents generated spikes, which could be clustered in doublets-triplets or longer bursts occurring at a frequency of 3-10/sec (Fig. 1A,B) [also see D'Angelo et al. (1998), their Figs. 1, 2]. Spikes were followed by a fast afterhyperpolarization (AHP), an afterdepolarization, and a slow afterhyperpolarization (Fig. 1B). When stronger depolarizing currents were injected, firing became regular, and afterdepolarization and slow afterhyperpolarization were no longer observed (Fig. $1 \mathrm{~A}$, top trace). It should be noted that recordings were performed in the presence of $10 \mu \mathrm{M}$ bicuculline preventing granule cell rhythmic inhibition by Golgi cells (Brickley et al., 1996) and that spontaneous EPSPs were too rare $(\sim 0.1 / \mathrm{sec})$ to significantly affect spike generation (no difference was noted after application of the glutamate receptor blockers $10 \mu \mathrm{M}$ CNQX, $100 \mu \mathrm{M}$ APV, 
and $50 \mu \mathrm{M}$ 7-Cl-kyn; $n=3$; data not shown). Thus, intrinsic membrane mechanisms should generate spike bursts, slow afterhyperpolarization (Alonso and Llinas, 1989; Gutfreund et al., 1995; Pape and Driesang, 1998), and spike afterdepolarization (Azouz et al., 1996; Raman and Bean, 1997).

Injection of sinusoidal currents of appropriate amplitude generated spike bursts in correspondence with the positive phase of the stimulus (Fig. $2 A$ ). Spike frequency within bursts increased and then decreased with injected current frequency, therefore showing resonance. The resonance frequency was $8.9 \pm 3.2 \mathrm{~Hz}(n=8$; average data are shown in Fig. $10 A)$. Resonance was also observed in the absence of spikes $(1 \mu \mathrm{M}$ TTX in the bath) (Fig. $2 B$ ). In this case, the maximum depolarization reached during the positive phase of the sinusoidal voltage response showed a resonance frequency of $8.1 \pm 2.9 \mathrm{~Hz}$ $(n=8$; average data are shown in Fig. $10 \mathrm{~B})$. Regarding both spike frequency and membrane potential measurements, the resonance frequency tended to increase slightly with the intensity of the injected current (Fig. $2 A, B$; see Fig. $10 A, B$ ).

\section{Evidence for a $\mathrm{K}^{+}$-dependent mechanism in oscillation and resonance}

The results shown in Figures 1 and 2 suggest that granule cells combine membrane mechanisms that generate fast repetitive firing, with others responsible for slow oscillations and resonance in the theta-frequency range. Accordingly, previous observations unveiled oscillations that sustained spike bursting by reducing $\mathrm{K}^{+}$ conductances with TEA and showed that they depended on a persistent TTX-sensitive $\mathrm{Na}^{+}$current (D'Angelo et al., 1998). Here we investigated the ionic dependence of the slow oscillatory mechanism and of resonance during bath application of $1 \mathrm{~mm}$ $\mathrm{Ni}^{2+}$, which fully blocks granule cell $\mathrm{Ca}^{2+}$ currents (Rossi et al., 1994; Tottene et al., 1996; D'Angelo et al., 1997, 1998), and of 4 mM 4-AP and $20 \mathrm{~mm}$ TEA, which block the granule cell $\mathrm{K}^{+}$ currents $I_{\mathrm{K}-\mathrm{V}}, I_{\mathrm{K}-\mathrm{Ca}}$, and $I_{\mathrm{K}-\mathrm{A}}$ (Cull-Candy et al., 1989; Bardoni and Belluzzi, 1993).

When these ionic channel blockers were used, depolarizing current steps sustained large-size oscillations surmounted by a solitary spike when the patch pipette solution contained $\mathrm{K}^{+}(n=$ $5)$ but not when it contained $\mathrm{Cs}^{+}(n=6)$ as the main intracellular cation (Fig. $3 A$ ). In these recordings, a marked adaptation prevented repetitive spike activation and bursting. Oscillations and solitary spikes were blocked by $1 \mu \mathrm{M}$ TTX, unveiling their $\mathrm{Na}^{+}$ dependence. Likewise, resonance was observed when the patch pipette contained $\mathrm{K}^{+}(n=3)$ but not when it contained $\mathrm{Cs}^{+}(n=$ 3) (Fig. $3 B$ ). Because $\mathrm{Cs}^{+}$prevents $\mathrm{K}^{+}$permeation through $\mathrm{K}^{+}$ channels, and because $\mathrm{Ca}^{2+}$ channels in these recordings are blocked, oscillation and resonance are likely to involve a TEAinsensitive $\mathrm{Ca}^{2+}$-independent $\mathrm{K}^{+}$current.

\section{Isolation of a slow $\mathrm{K}^{+}$current in granule cells}

A TEA-insensitive $\mathrm{Ca}^{2+}$-independent slow outward current $\left(I_{\mathrm{K} \text {-slow }}\right)$ was isolated by performing voltage-clamp recordings in the presence of $20 \mathrm{~mm}$ TEA, $4 \mathrm{~mm} 4-\mathrm{AP}, 1 \mathrm{~mm} \mathrm{Ni}^{2+}$, and $1 \mu \mathrm{M}$ TTX (Fig. 4). $I_{\mathrm{K} \text {-slow }}$ could not be measured in cells internally perfused with $\mathrm{Cs}^{+}$rather than $\mathrm{K}^{+}$(data not shown), which revealed its $\mathrm{K}^{+}$dependence, and was reversibly reduced by $48.7 \pm 8.4 \%(n=4)$ by extracellular perfusion of $1 \mathrm{~mm} \mathrm{Ba}{ }^{2+}$ (Fig. $4 A$ ).

During application of depolarizing voltage steps from the holding potential of $-80 \mathrm{mV}$ (Fig. $4 B$ ), $I_{\mathrm{K} \text {-slow }}$ activated around -40 $\mathrm{mV}$, and its amplitude increased by increasing the test potential.
A
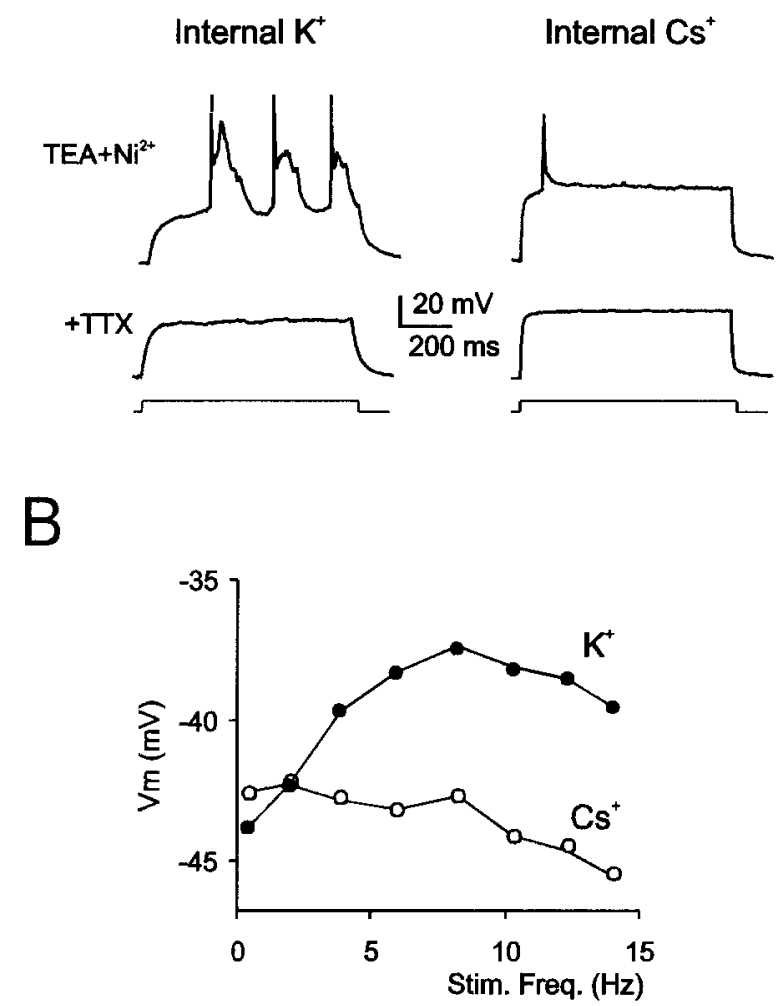

Figure 3. $\mathrm{K}^{+}$dependence of slow oscillation and resonance. Currentclamp recordings were performed in the presence of $20 \mathrm{~mm}$ TEA, $4 \mathrm{~mm}$ 4-AP, and $1 \mathrm{mM} \mathrm{Ni}^{2+}$. A, A sustained slow oscillation is observed in granule cells recorded with $\mathrm{K}^{+}$-containing patch pipette during step current injection $(10 \mathrm{pA}$ from $-80 \mathrm{mV})$. A solitary action potential is generated in a different cell recorded with a $\mathrm{Cs}^{+}$-containing patch pipette. In both cases, excitable responses were abolished by $1 \mu \mathrm{M}$ TTX. $B$, Resonance curves in a cell recorded with $\mathrm{K}^{+}(\mathbf{0})$ and in another cell recorded with $\mathrm{Cs}^{+}(\bigcirc)$ inside the patch pipette. Comparable voltage responses in neurons shown in $A$ and $B$ were obtained by properly adjusting the intensity of injected current (lower with $\mathrm{Cs}^{+}{ }_{-}$than with $\mathrm{K}^{+}$-containing pipettes).

$I_{\mathrm{K} \text {-slow }}$ rising phase was well fitted by a single exponential function (Fig. 4B, inset), indicating first-order activation kinetics. Exponential time constants ranged from 10 to $>100 \mathrm{msec}$ for test potentials between -40 and $0 \mathrm{mV}$, reaching values two orders of magnitude higher than those of other granule cell outward currents (Cull-Candy et al., 1989; Bardoni and Belluzzi, 1993). $I_{\mathrm{K} \text {-slow }}$ persisted for $>1 \mathrm{sec}$, but in six of nine cells it showed a slight tendency to inactivate at positive test potentials $(<15 \%$ after $1 \mathrm{sec}$ at $+30 \mathrm{mV}$ ).

Voltage jumps to different potentials after a $300 \mathrm{msec}$ conditioning pulse at $+30 \mathrm{mV}$ (when $I_{\mathrm{K} \text {-slow }}$ was almost fully activated) generated tail currents that relaxed with an exponential time course (Fig. 4C). Exponential fitting (Fig. 4B, inset) yielded the activation time constant, the instantaneous tail current amplitude (time $=0$ ), and the steady-state current. According to the Nernstian equilibrium potential of $\mathrm{K}^{+}$ions, the instantaneous tail current was zero at $-74.8 \pm 5.5 \mathrm{mV}(n=4)$ and shifted to $-37.7 \pm 6.1 \mathrm{mV}(n=4)$ when extracellular $\mathrm{K}^{+}$was raised to 25 mM by equimolar $\mathrm{Na}^{+}$substitution.

Voltage dependence of the steady-state current and the activation time constant obtained from data shown in Figure 4, $A$ and 

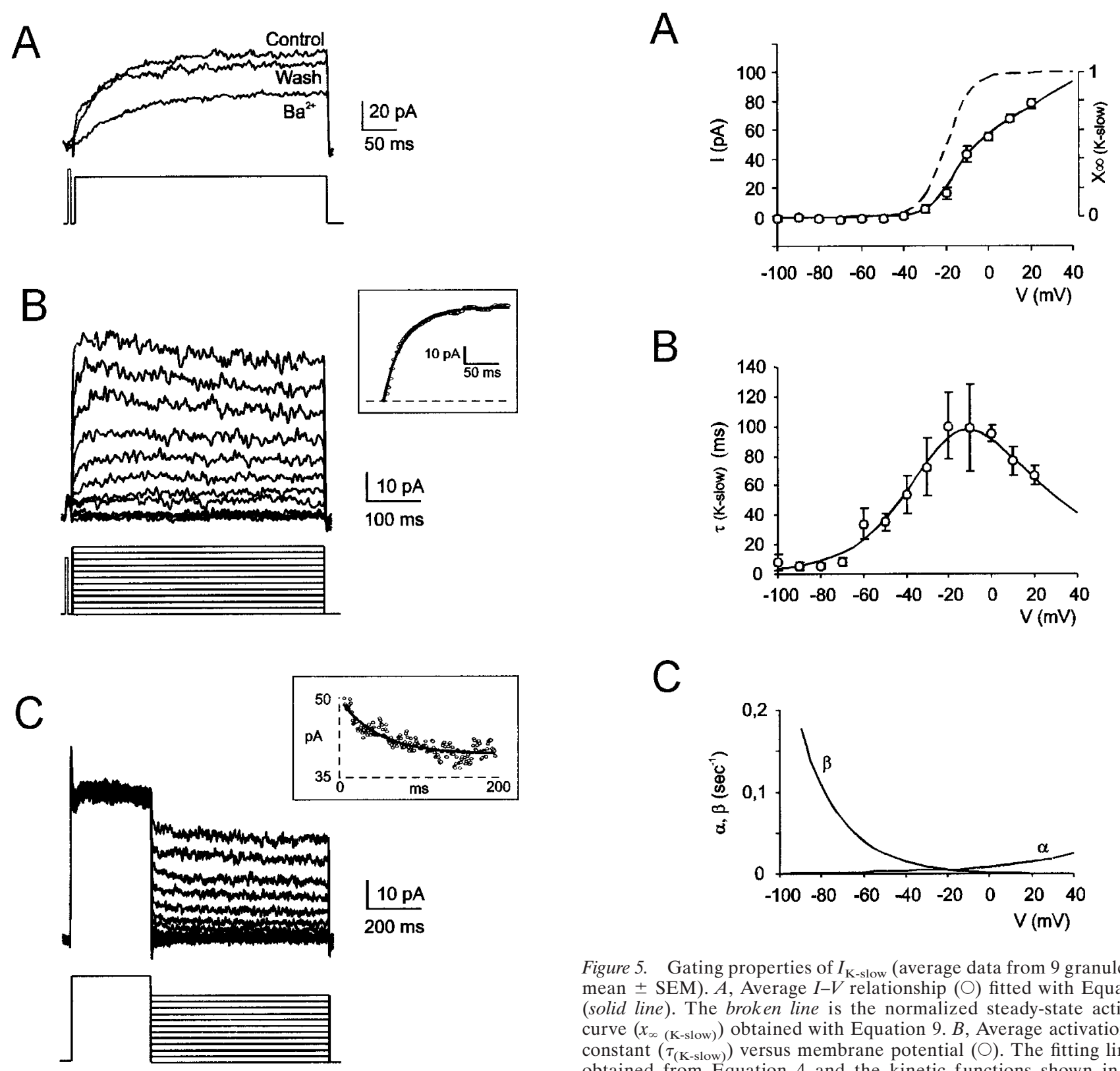

Figure 5. Gating properties of $I_{\mathrm{K} \text {-slow }}$ (average data from 9 granule cells, mean $\pm \mathrm{SEM}) . A$, Average $I-V$ relationship $(\bigcirc)$ fitted with Equation 8 (solid line). The broken line is the normalized steady-state activation curve $\left(x_{\infty}\right.$ (K-slow) $)$ obtained with Equation 9. B, Average activation time constant $\left(\tau_{(\mathrm{K} \text {-slow })}\right)$ versus membrane potential $(O)$. The fitting line was obtained from Equation 4 and the kinetic functions shown in $C$. $C$, Voltage dependence of the kinetic constants $\alpha$ and $\beta$ (see Eq. 3 and Table 1).
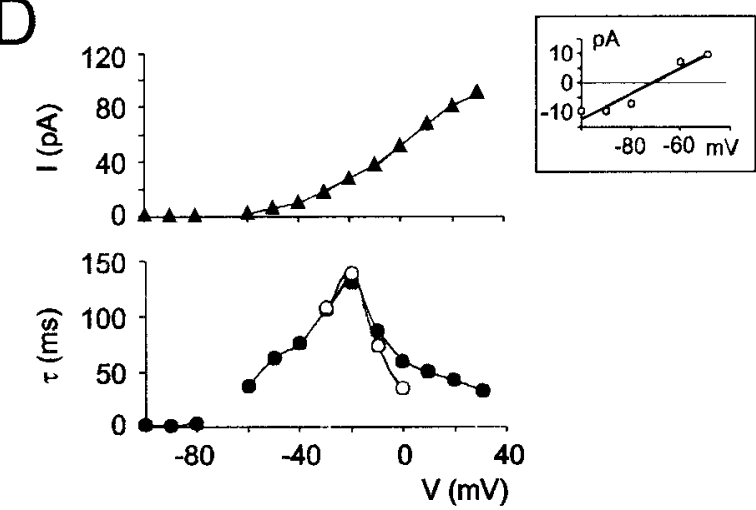

Figure 4. Isolation of a slow $\mathrm{K}^{+}$current, $I_{\mathrm{K} \text {-slow }}$, in the presence of $20 \mathrm{~mm}$ TEA, $4 \mathrm{~mm} 4$-AP, $1 \mathrm{~mm} \mathrm{Ni}^{2+}$, and $1 \mu \mathrm{M}$ TTX. $A$, $I_{\mathrm{K} \text {-slow }}$ was generated by a voltage pulse from -80 to $+30 \mathrm{mV}$. $I_{\mathrm{K} \text {-slow }}$ was reversibly inhibited by application of $1 \mathrm{mM} \mathrm{Ba}^{2+} . B, I_{\mathrm{K} \text {-slow }}$ activation was investigated by applying $1 \mathrm{sec}, 10 \mathrm{mV}$ depolarizing voltage steps from the holding potential of -80 $\mathrm{mV}$ (a short pre-step was applied to inactivate $I_{\mathrm{K}-\mathrm{A}}$ ) (Bardoni and Belluzzi,

1993). The inset shows exponential fitting to the rising phase of a current recorded at $0 \mathrm{mV}$ with the function $I(t)=I_{\mathrm{ss}} *\left(1-\exp \left(-t / \tau_{\text {act }}\right)\right)$, where $I_{\mathrm{ss}}=53 \mathrm{pA}$ is the steady-state current and $\tau_{\text {act }}=33.5 \mathrm{msec}$ is the activation time constant. $C, I_{\mathrm{K} \text {-slow }}$ deactivation was investigated by using voltage jumps to different potentials after a $300 \mathrm{msec}$ conditioning pulse at $+30 \mathrm{mV}$ (holding potential $=-80 \mathrm{mV}$ ). The inset shows exponential fitting to a tail current recorded at $-10 \mathrm{mV}$ with the function $I(t)=I_{\mathrm{ss}}+I_{0} * \exp (-t)$ $\left.\tau_{\text {deact }}\right)$, where $\left(I_{\mathrm{o}}+I_{\mathrm{ss}}\right)=48.9 \mathrm{pA}$ is the instantaneous current, $I_{\mathrm{ss}}=39.2$ $\mathrm{pA}$ is the steady-state current, and $\tau_{\text {deact }}=46.9 \mathrm{msec}$ is the deactivation time constant. $D$, Voltage dependence of steady-state amplitude of deactivation curves $\left(I_{\mathrm{ss}}, \boldsymbol{\Delta}\right)$, and of time constants obtained by exponential fitting to activation $\left(\tau_{\text {act }}, \bigcirc\right)$ and deactivation $\left(\tau_{\text {deact }}, 0\right)$ curves. The inset shows intersection of the linear regression curve to instantaneous tail current amplitude with the voltage axis at $-71.4 \mathrm{mV}$. Data in $B-D$ were obtained from the same granule cell. 


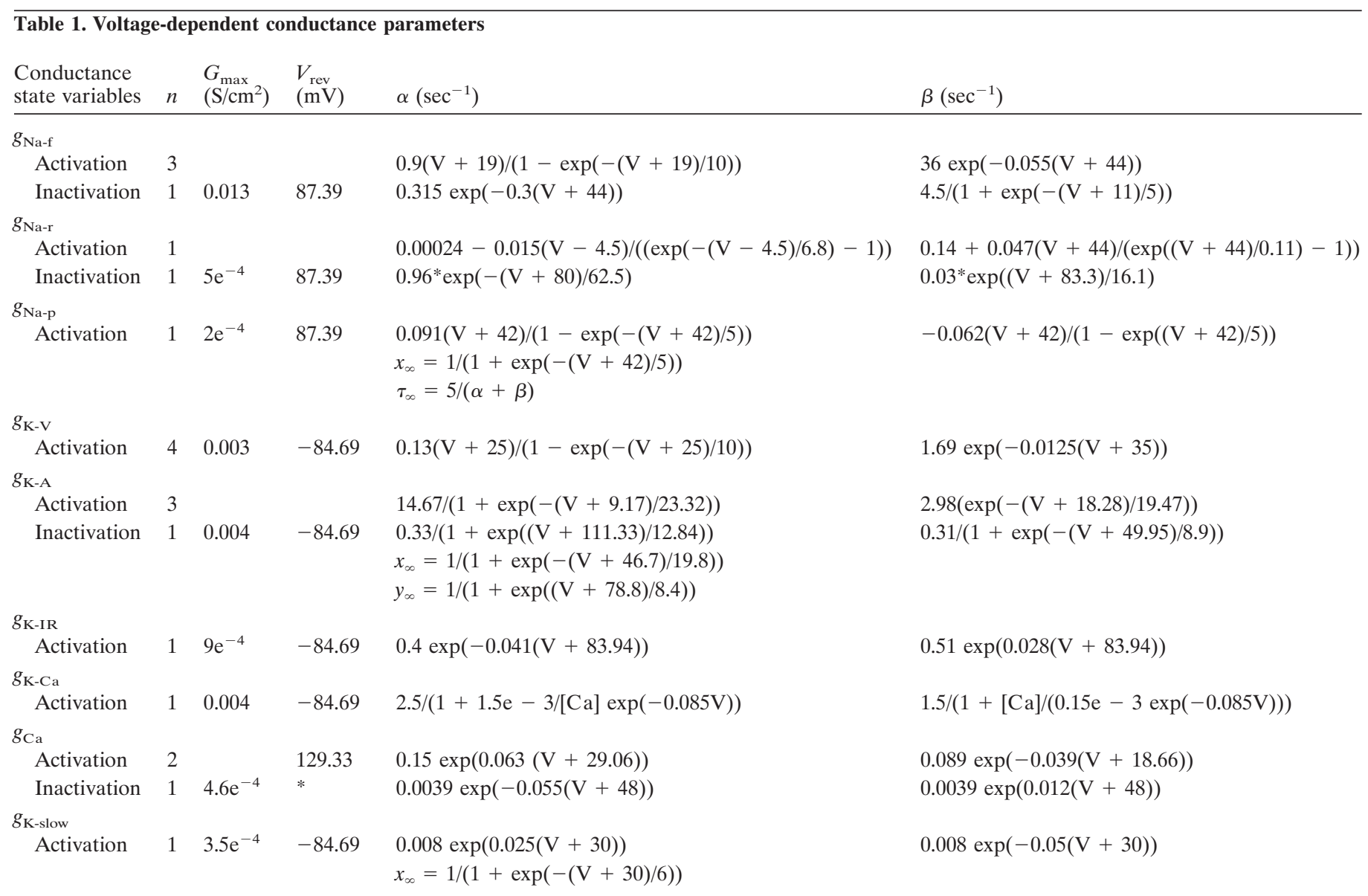

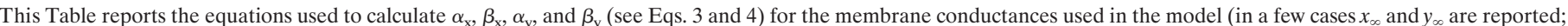

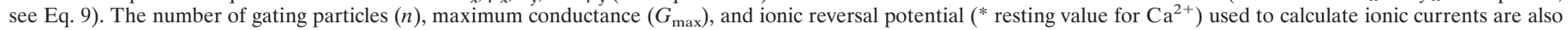
shown.

$B$, are shown in Figure $4 D$. The $I-V$ curve showed outward rectification, and the activation time constant showed a bellshaped voltage dependence. It should be noted that time constants measured from activation and deactivation currents coincided, consistent with a first-order gating mechanism. However, deactivation currents were preferred to activation currents for gating reconstruction, because they covered a more extended membrane potential range and were free of potential contamination by $I_{\mathrm{K}-\mathrm{A}}$, which is not completely blocked even by $4 \mathrm{~mm} 4$-AP in cerebellar granule cells (Bardoni and Belluzzi, 1993).

Figure 5 shows average data obtained from nine granule cell recordings. The $I-V$ curve (Fig. $5 A$ ) was fitted with a Boltzman equation of the form [see Rossi et al. (1998)]:

$$
I(V)=\left[G_{\max }\left(V-V_{\text {rev }}\right)\right] /\left[1+\exp \left(\left(V-V_{1 / 2}\right) / k\right)\right]
$$

where $G_{\max }=0.8 \mathrm{nS}$ is the maximum conductance, $V_{\mathrm{rev}}=-70.2$ $\mathrm{mV}$ is the reversal potential, $V_{1 / 2}=-20 \mathrm{mV}$ is the half-activation potential, and $k=6 \mathrm{mV}^{-1}$ is the activation voltage dependence. These parameters were used to reconstruct steady-state $I_{\mathrm{K} \text {-slow }}$ activation (Fig. $5 A$ ) by using the equation:

$$
G(V) / G_{\max }=1 /\left[1+\exp \left(\left(V-V_{1 / 2}\right) / k\right)\right] .
$$

The relationship between activation time constant and voltage (Fig. $5 B$ ) was fitted by Equation 4 using the kinetic constants shown in Figure 5C. As in other ionic current models (Gutfreund et al., 1995; Mainen et al., 1995), independent expressions for the activation time constant and steady-state activation improved data representation. These results allowed $I_{\mathrm{K} \text {-slow }}$ reconstruction according to a first-order Hodgkin-Huxley kinetic scheme (Yamada et al., 1998) (see Materials and Methods; Table 1).

\section{Mathematical reconstruction of intrinsic excitability}

To investigate the role of $I_{\mathrm{K} \text {-slow }}$ in oscillations, bursting, and resonance, we developed a mathematical model of granule cell excitability (see Materials and Methods; Table 1). With $I_{\mathrm{Na}-\mathrm{f}}, I_{\mathrm{Ca}}$, $I_{\mathrm{K}-\mathrm{V}}, I_{\mathrm{K}-\mathrm{Ca}}, I_{\mathrm{K}-\mathrm{A}}$, and $I_{\mathrm{K}-\mathrm{IR}}$, the model generated inward rectification and fast repetitive firing (Gabbiani et al., 1994). The model was then endowed with a persistent $\mathrm{Na}^{+}$current $\left(I_{\mathrm{Na}-\mathrm{p}}\right)$

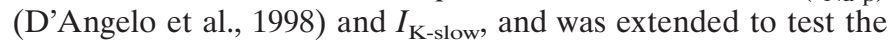
potential contribution of a resurgent $\mathrm{Na}^{+}$current $\left(I_{\mathrm{Na}-\mathrm{r}}\right)$ (Raman and Bean, 1997). With $I_{\mathrm{Na}-\mathrm{p}}, I_{\mathrm{K} \text {-slow }}$, and $I_{\mathrm{Na}-\mathrm{r}}$, just-threshold step current injection generated membrane potential oscillations and spike bursts, with the spikes showing fast- and slow-afterhyperpolarization and afterdepolarization (Fig. 6A,B). With stronger current injection, the model generated regular repetitive firing (Fig. 6A; see Fig. 8). Moreover, the model reproduced TEAinduced bursting (see Fig. 9) and intrinsic resonance (see Fig. 10).

\section{The ionic mechanism of slow oscillations}

Model simulations showed that $I_{\mathrm{Na}-\mathrm{p}}$ and $I_{\mathrm{K} \text {-slow }}$ were sufficient to generate regular theta-frequency oscillations, which were elimi- 


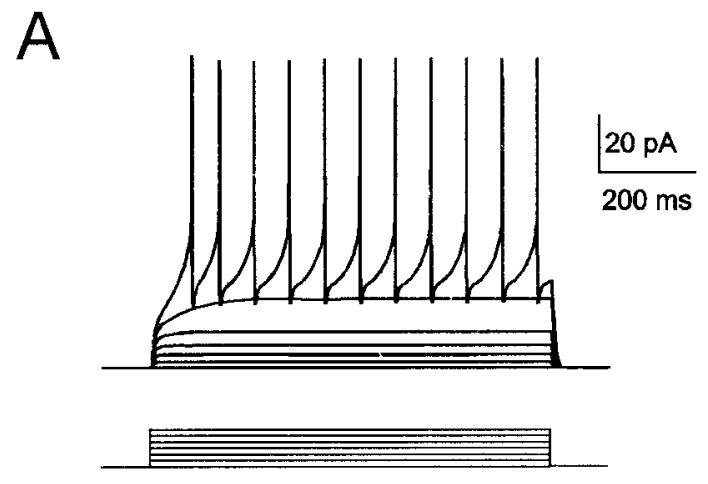

B
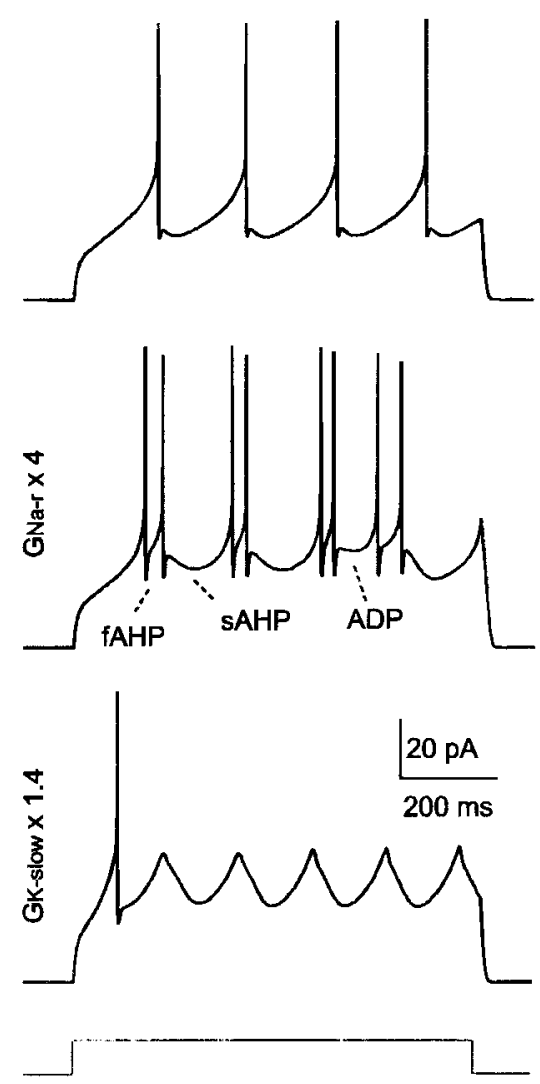

Figure 6. Mathematical modeling of granule cell excitability. $A$, Model responses to $2 \mathrm{pA}$ step current injection from $-80 \mathrm{mV}$. The model generates inward rectification in subthreshold responses, followed by regular repetitive firing with almost no adaptation. $B$, Slow oscillations, slow afterhyperpolarization, occasional uncoupling of spike prepotential from upstroke, and spike bursts can be generated by the model by using just-threshold stimulation (10.5 pA in the top and middle tracings, $12 \mathrm{pA}$ in the bottom tracing). The shape of oscillations and bursting could be modified by changing the $G_{\mathrm{Na} \text {-r }}$ or $G_{\mathrm{K} \text {-slow }}$ intensities.

nated when either of these currents was turned off (Fig. 7A). During oscillations, $I_{\mathrm{Na} \text {-p }}$ and $I_{\mathrm{K} \text {-slow }}$ showed activation/deactivation cycles describing stable orbits in the phase plane (Fig. $7 B$ ). The histerisis observed in $I_{\mathrm{K} \text {-slow }}$ (and to a lesser extent in $I_{\mathrm{Na}-\mathrm{p}}$ ) trajectory reflected its delayed gating during membrane potential changes.

The model generated repetitive oscillations when $G_{\mathrm{K}-\mathrm{V}}, G_{\mathrm{K}-\mathrm{Ca}}$, and $G_{\mathrm{Ca}}$ were set to zero, reproducing the pharmacological application of $20 \mathrm{~mm}$ TEA and $1 \mathrm{~mm} \mathrm{Ni}^{2+}$ (Fig. $7 C$; compare Fig. 2). Moreover, the model generated a solitary $\mathrm{Ca}^{2+}$ action potential when $G_{\mathrm{K}-\mathrm{V}}, G_{\mathrm{K}-\mathrm{Ca}}$, and $G_{\mathrm{Na}}$ were set to zero, reproducing the pharmacological application of $20 \mathrm{~mm}$ TEA and $1 \mu \mathrm{M}$ TTX (Fig. 7D) [compare Fig. 3 in D'Angelo et al. (1998) and Fig. 10 in D'Angelo et al. (1997)]. Modeling results therefore indicated that slow oscillations in granule cells depend on the interaction of $I_{\mathrm{Na}-\mathrm{p}}$ and $I_{\mathrm{K} \text {-slow }}$ but are independent from $\mathrm{Ca}^{2+}$ currents.

\section{Repetitive firing}

Figure $8 A$ shows repetitive firing in the model. As in experimentally recorded granule cell responses (D'Angelo et al., 1995, 1998; Brickley et al., 1996), spikes showed negligible adaptation, and first-spike latency decreased whereas spike frequency increased when the injected current intensity was raised. The frequencyintensity $(f-I)$ plot was almost linear between 0 and $100 \mathrm{~Hz}$, with a slope of 7.3 spikes per $\mathrm{pA}^{-1} \cdot \mathrm{sec}^{-1}$.

Spikes were generated by a sudden $I_{\mathrm{Na}-\mathrm{f}}$ raise followed by activation of $I_{\mathrm{K}-\mathrm{V}}$ and the $I_{\mathrm{Ca}} / I_{\mathrm{K}-\mathrm{Ca}}$ system (Fig. $8 B$ ). The intracellular $\mathrm{Ca}^{2+}$ wave peaked after the spike and decayed to zero in $\sim 3$ msec. $I_{\mathrm{Na}-\mathrm{f}}, I_{\mathrm{K}-\mathrm{V}}, I_{\mathrm{Ca}}$, and $I_{\mathrm{K}-\mathrm{Ca}}$ accounted for most of the active current during the spike and the fast AHP, whereas other currents were two orders of magnitude smaller. $I_{\mathrm{Na}-\mathrm{p}}$ increased during the spike prepotential and persisted for several milliseconds. $I_{\mathrm{Na}-\mathrm{r}}$ increased just after the spike. $I_{\mathrm{K}-\mathrm{A}}, I_{\mathrm{K}-\mathrm{IR}}$, and $I_{\mathrm{K} \text {-slow }}$ were mostly active during the interspike trajectory. Thus, whereas $I_{\mathrm{Na}-\mathrm{p}}$ and $I_{\mathrm{Na-r}}$ enhanced spike activation, $I_{\mathrm{K}-\mathrm{A}}, I_{\mathrm{K}-\mathrm{IR}}$, and $I_{\mathrm{K} \text {-slow }}$ delayed it. The regulatory action of $I_{\mathrm{Na}-\mathrm{r}}$ and $I_{\mathrm{K}-\mathrm{A}}$ on spike frequency is shown in the plots of Figure $8 A$.

\section{TEA-induced bursting}

Figure $9 A$ illustrates theta-frequency bursting in the model after partial $I_{\mathrm{K}-\mathrm{Ca}}$ blockage, simulating experimental TEA application (D'Angelo et al., 1998, their Figs. 6 and 8). A relatively modest $I_{\mathrm{K}-\mathrm{Ca}}$ blockage caused spike doublets-triplets, whereas stronger blockage caused marked membrane potential oscillations surmounted by adapting spike bursts. Thus, $I_{\mathrm{K}-\mathrm{Ca}}$ prevented activation of the $I_{\mathrm{Na}-\mathrm{p}} / I_{\mathrm{K} \text {-slow }}$ oscillatory mechanism. Bursting was enhanced by $I_{\mathrm{Na}-\mathrm{r}}$ (Fig. $9 A$, compare left with right column), but no bursting was generated by $I_{\mathrm{Na}-\mathrm{r}}$ alone when the $I_{\mathrm{Na}-\mathrm{p}} / I_{\mathrm{K}-\text { slow }}$ mechanism was turned off (Fig. 9A, bottom panel).

TEA-induced bursting was characterized by a remarkable rise in $I_{\mathrm{Na} \text {-p }}$ associated with a progressive $I_{\mathrm{K} \text {-slow }}$ activation (Fig. $9 B$, compare Fig. $7 B$ ). During the burst, $I_{\mathrm{Na}-\mathrm{f}}$ inactivation caused spike amplitude adaptation.

\section{Resonance}

Injecting the granule cell model with sinusoidal currents of different frequency generated resonant responses. Resonance in burst spike frequency is shown in Figure $10 A$, and resonance in maximum membrane depolarization (with spikes blocked by setting $I_{\mathrm{Na}-\mathrm{f}}, I_{\mathrm{Na}-\mathrm{p}}$, and $I_{\mathrm{Na}-\mathrm{r}}$ to zero mimicking TTX block) is shown in Figure $10 B$. In both cases a family of resonant curves is shown, one of which matches average experimental measurements from a set of five granule cells.

The model was used to investigate the ionic mechanisms of resonance. Resonance was eliminated by blocking $I_{\mathrm{K} \text {-slow }}$, which determined the ascending branch of resonance curves (Fig. $11 A, B)$. The descending branch of resonance curves was determined by passive membrane filtering, as demonstrated by its persistence when the ionic channels involved in resonance were blocked. In addition, $I_{\mathrm{K}-\mathrm{A}}$ markedly accelerated the descending 


\section{A}

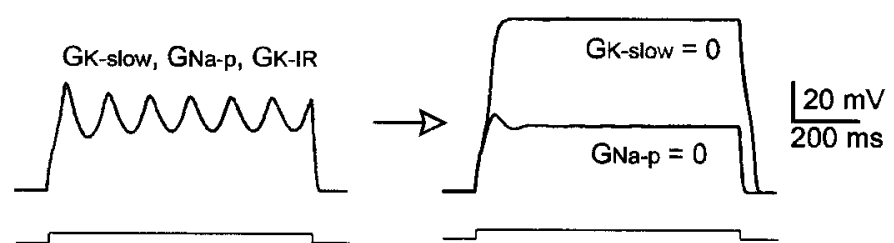

B

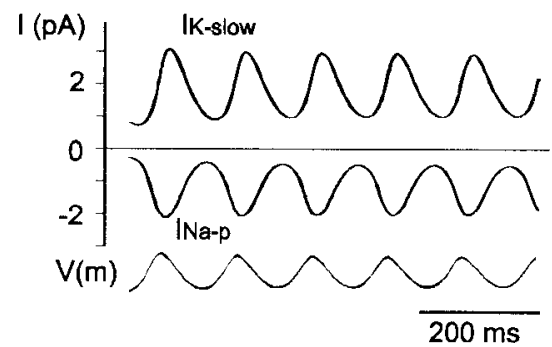

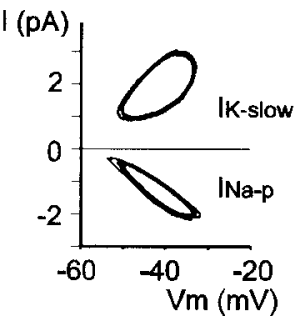

C

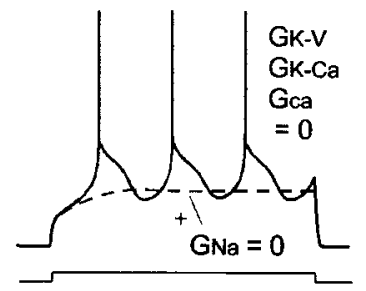

D

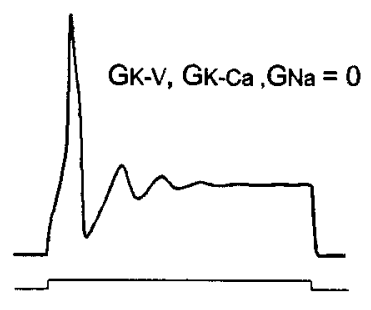

Figure 7. The oscillatory mechanism in granule cells. $A$, Simulation of stable oscillations sustained by $G_{\mathrm{K} \text {-slow }}$ and $G_{\mathrm{Na} \text {-p }}$ during injection of an 11 pA current step. Oscillations are eliminated by turning off either $G_{\mathrm{K} \text {-slow }}$ or $G_{\mathrm{Na}-\mathrm{p}}$. All other active conductances were set to zero except $G_{\mathrm{K}-\mathrm{IR}}$, which was used to keep input conductance close to its normal value. $B$, Time course and phase-plane trajectory of $I_{\mathrm{K} \text {-slow }}$ and $I_{\mathrm{Na}-\mathrm{p}}$ during membrane potential oscillations (dotted line). $C$, Voltage responses to an $11 \mathrm{pA}$ current step simulating TEA $\left(G_{\mathrm{K}-\mathrm{v}}=0, G_{\mathrm{K}-\mathrm{Ca}}=0\right)$, and Ni ${ }^{2+}\left(G_{\mathrm{Ca}}=0\right)$ application. The broken line simulates subsequent application of TTX $\left(G_{\mathrm{Na}}=0\right)$. $D$, Voltage responses to an 11 pA current step simulating TEA $\left(G_{\mathrm{K}-\mathrm{V}}=0, G_{\mathrm{K}-\mathrm{Ca}}=0\right)$ and TTX $\left(G_{\mathrm{Na}}=0\right)$ application. Same calibration in $A, C$, and $D$.

A

$12 \mathrm{pA}$
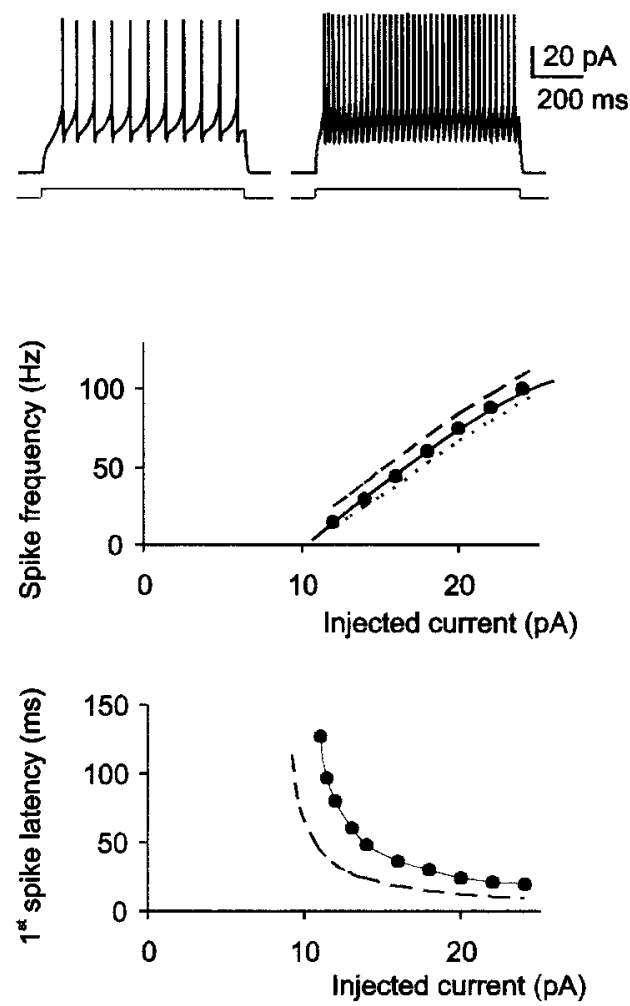

B

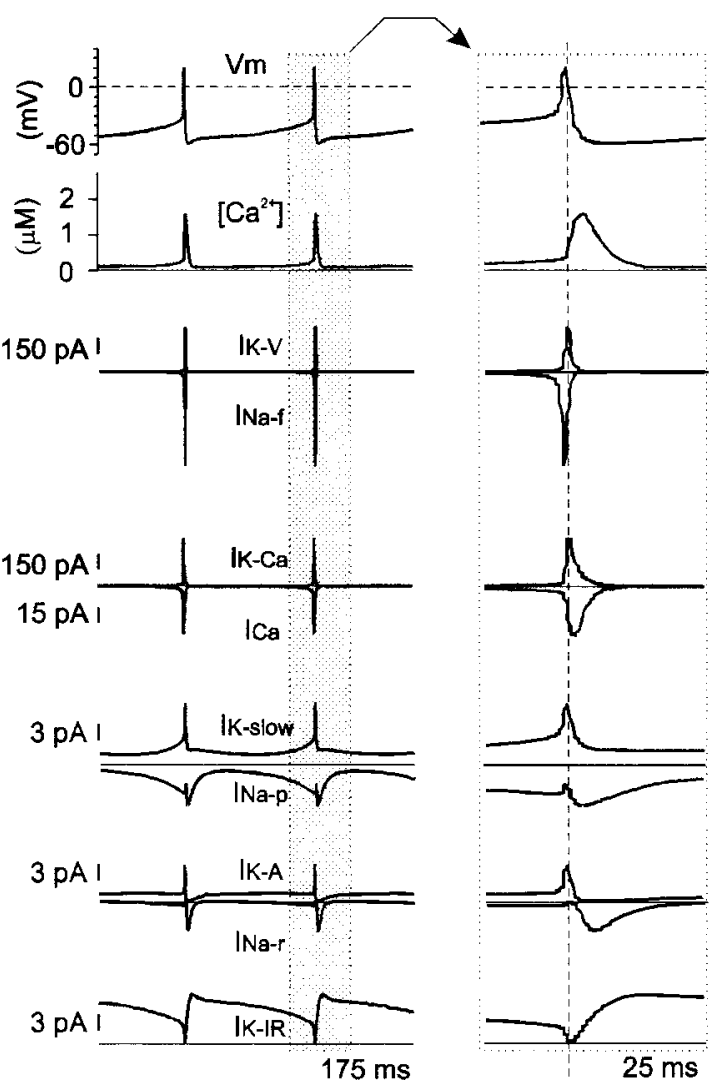

Figure 8. Ionic mechanisms of repetitive firing. A, Model tracings show regular firing with negligible adaptation at $>100 \mathrm{~Hz}$. The top plot $(f-I$ plot) reports firing frequency in control conditions $(-)$ and after having turned off $I_{\mathrm{K}-\mathrm{A}}$ (broken line) or $I_{\mathrm{Na}-\mathrm{r}}$ (dotted line). The bottom plot shows first-spike latency in control conditions $(\bullet)$ and after having turned off $I_{\mathrm{K}-\mathrm{A}}$ (broken line). $B$, Ionic currents and [Ca ${ }^{2+}$ ] changes during repetitive firing. The right set of tracings is an enlargement of currents associated with an action potential. Note that both $I_{\mathrm{Na}-\mathrm{p}}$ and $I_{\mathrm{Na}-\mathrm{r}}$ are activated after the spike. 
A

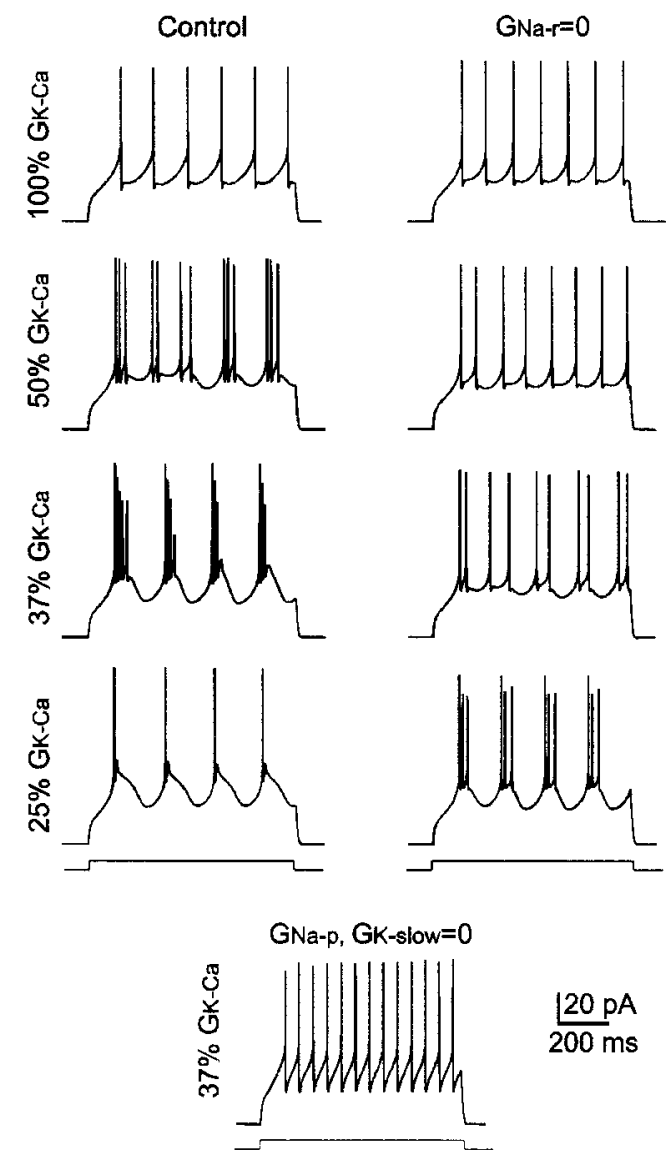

B
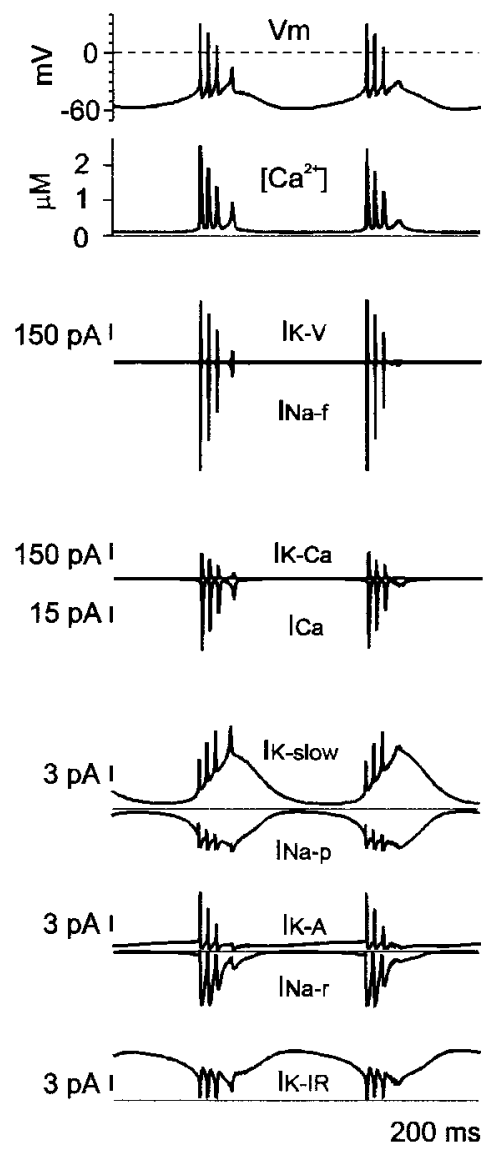

Figure 9. Ionic mechanisms of bursting. $A$, Tracings show intensification of bursting and spike adaptation by progressively increasing $G_{\mathrm{K}-\mathrm{Ca}}$ inhibition during injection of $11 \mathrm{pA}$ current steps. Stronger $G_{\mathrm{K}-\mathrm{Ca}}$ inhibition is needed to generate bursting when $G_{\mathrm{Na}-\mathrm{r}}$ is set to zero. No bursting is generated when $G_{\mathrm{Na}-\mathrm{p}}$ and $G_{\mathrm{K} \text {-slow }}$ are turned off, but $G_{\mathrm{Na-r}}$ is left active. $B$, Ionic currents and $\left[\mathrm{Ca}^{2+}\right]$ changes during bursting elicited with $I_{\mathrm{K}-\mathrm{Ca}}$ reduction to $37 \%$ of its normal value. Note that $I_{\mathrm{K} \text {-slow }}$ and $I_{\mathrm{Na}-\mathrm{p}}$ are greatly enhanced during bursting compared with repetitive firing.

A

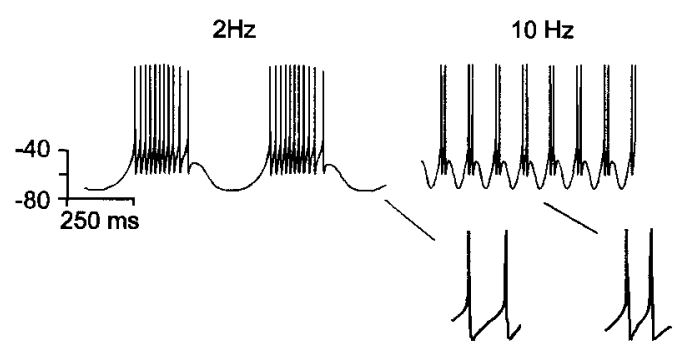

B

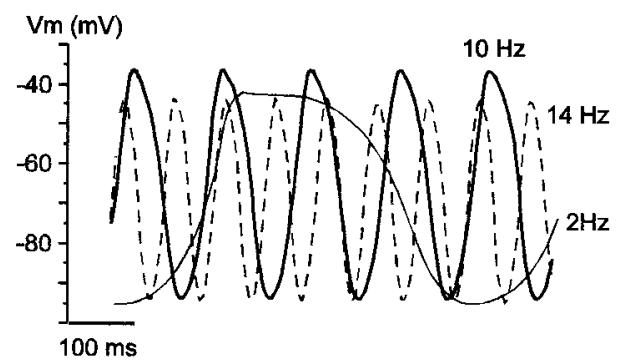

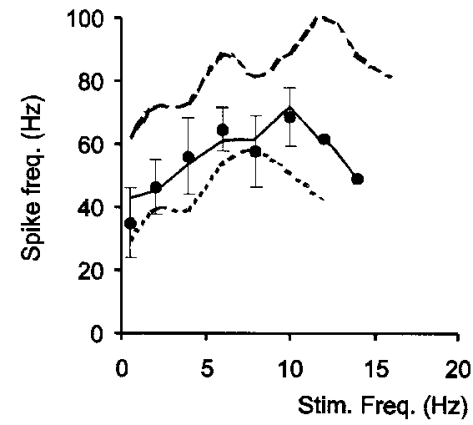

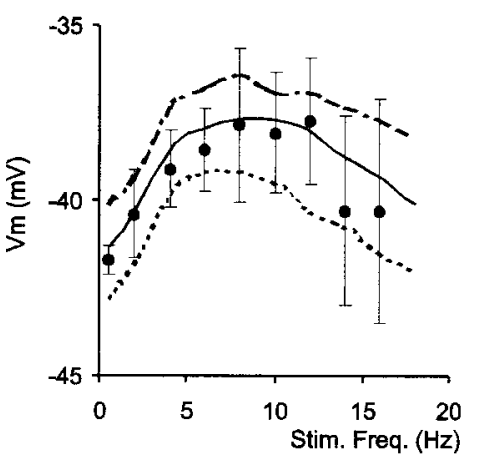

Figure 10. Ionic mechanisms of resonance. $A$, Injection of sinusoidal currents causes oscillatory bursting in the model. Tracings are generated by a $\pm 6 \mathrm{pA}$ sinusoidal current superimposed on a $12 \mathrm{pA}$ current step. Insets show higher spike frequency in bursts generated at $10 \mathrm{~Hz}$ than at $2 \mathrm{~Hz}$. The plot shows model resonance with three different sinusoidal current intensities $( \pm 4, \pm 6$, or $\pm 8 \mathrm{pA}$ superimposed on a constant $12 \mathrm{pA}$ current step). The curve generated with $\pm 6 \mathrm{pA}$ is a good match with the average experimental response (- mean $\pm \mathrm{SD} ; n=5)$. $B$, Same as in $A$, except that maximum membrane depolarization during the positive phase of sinusoidal voltage responses is measured with $I_{\mathrm{Na-f}}, I_{\mathrm{Na}-\mathrm{p}}$, and $I_{\mathrm{Na-r}}$ set to zero. This result is compared with experimental recordings in the presence of $1 \mu \mathrm{M}$ TTX $(-$; mean $\pm \mathrm{SD}$; $n=5$, same cells as in $A$ ). As with real granule cells, the model shows resonance $\sim 10$ $\mathrm{Hz}$. 
branch. Enhanced activation of $I_{\mathrm{K} \text {-slow }}$ at low frequency and $I_{\mathrm{K}-\mathrm{A}}$ at high frequency is shown in Figure $11 C$. It should be noted that resonance was not eliminated by blocking $I_{\text {Na-p }}$ (Fig. 11A,B), which showed minor frequency-dependent changes (Fig. 11C). Finally, $I_{\mathrm{Na}-\mathrm{r}}$ (in the case of burst spike frequency) decelerated the descending branch of resonance curves.

\section{DISCUSSION}

This study shows that in addition to generating fast repetitive firing, cerebellar granule cells generate oscillations, bursting, and resonance in the theta-frequency range. Experimental and modeling results indicated that these aspects of intrinsic excitability require a slow $\mathrm{K}^{+}$current $\left(I_{\mathrm{K} \text {-slow }}\right)$ to be generated.

$I_{\mathrm{K} \text {-slow }}$ is a $\mathrm{Ca}^{2+}$-independent TEA-insensitive $\mathrm{K}^{+}$current activating in the spike threshold region with slow kinetics (10-100 msec). A current like $I_{\mathrm{K} \text {-slow }}$ has not been reported previously in cerebellar granule cells, although a persistent TEA-resistant current component was noted in cell culture (Cull-Candy et al., 1989) [also see Bardoni and Belluzzi (1993), their Fig. 10B]. $I_{\mathrm{K} \text {-slow }}$ biophysical and pharmacological properties are similar to those of $I_{\mathrm{M}}$ of vertebrate neurons (Brown and Adams, 1980; Adams et al., 1982a,b) and are suitable to generate the delayed repolarizing feedback and high-pass filtering required for bursting and resonance. Indeed, $I_{M}$ has been reported to sustain oscillations and resonance in amygdaloid neurons (Pape and Driesang, 1998) and in cortical pyramidal neurons (Gutfreund et al., 1995). Alternative mechanisms that might be invoked to explain bursting and resonance are unlikely to occur in cerebellar granule cells. (1) A slow inward rectifier current $\left(I_{\mathrm{h}}\right)$ (Dickson et al., 2000) and a slow $\mathrm{Ca}^{2+}$-dependent $\mathrm{K}^{+}$current $\left(I_{\mathrm{AHP}}\right)$ (Wang and Rinzel, 1999) are apparently not expressed in granule cells. Granule cell inward rectification is fully explained by a fast $\mathrm{K}^{+}$-dependent inward rectifier (Fig. 6A) (Rossi et al., 1998), and granule cell slow afterhyperpolarization is fully explained by $I_{\mathrm{K} \text {-slow }}\left(\right.$ Fig. $6 B$ ). It should also be noted that the $I_{\mathrm{AHP}}$ blocker apamin did not affect the excitable response, and oscillations and bursting persisted in the presence of $\mathrm{Ca}^{2+}$ channel blockers (Fig. 3) (D'Angelo et al., 1998). Moreover, contrary to what would be expected from $I_{\mathrm{AHP}}$, granule cell slow AHP occurred with just-threshold stimulation disappearing rather than being enhanced with higher spike frequency and was not associated with any spike frequency adaptation. (2) A resurgent current, $I_{\mathrm{Na}-\mathrm{r}}$, facilitated but proved not sufficient to induce bursting and resonance (Fig. 8A). (3) Finally, return currents from the dendrites, which might generate somatic rebound depolarization and spike bursting, are unlikely to be effective because of the granule cell compact electrotonic structure. Actually, with a $10 \mathrm{M} \Omega$ somatodendritic resistance (calculated assuming an axial resistance of $150 \Omega / \mathrm{cm}$ in a $20 \mu \mathrm{m}$ dendrite) and a somatodendritic ratio between 1 and 2 (Silver et al., 1992; D’Angelo et al., 1993; Gabbiani et al., 1994), no bursting is expected even if active conductances are expressed in the dendrites (Mainen and Sejinowsky, 1996).

Modeling reliability was based on the extensive characterization of membrane currents and the compact electrotonic structure of cerebellar granule cells (for details, see Materials and Methods). Indeed, patch-clamp recordings from mature cerebellar granule cells in situ have been used (1) to reconstruct $I_{\mathrm{Ca}}$ (Rossi et al., 1994), $I_{\mathrm{K}-\mathrm{IR}}$ (Rossi et al., 1998), $I_{\mathrm{K}-\mathrm{A}}$
Figure 11. Resonance regulation. This Figure shows resonance being regulated by injection of a $\pm 6 \mathrm{pA}$ sinusoidal current superimposed on a $12 \mathrm{pA}$ current step. $A$, Resonance in burst spike frequency in different conditions: $\boldsymbol{\bullet}$, control; $\square, I_{\mathrm{K} \text {-slow }}=0 ; \diamond, G_{\mathrm{K}-\mathrm{A}}=0 ; \Delta$, $G_{\mathrm{Na}-\mathrm{p}}=0 ; \nabla, G_{\mathrm{Na-r}}=0$. No resonance could be observed in the model when $I_{\text {Na-p }}, I_{\mathrm{K} \text {-slow }}$, and $I_{\text {Na-r }}$ were turned off (thin dotted line). B, Resonance in maximum membrane depolarization during the positive phase of sinusoidal voltage responses in different conditions: con$\operatorname{trol}\left(\Delta, I_{\mathrm{Na}-\mathrm{p}}, I_{\mathrm{Na}-\mathrm{f}}, I_{\mathrm{Na}-\mathrm{r}}=0\right.$; TTX condition); $\square, \mathrm{I}_{\mathrm{K} \text {-slow }}=0, \diamond, I_{\mathrm{K}-\mathrm{A}}=0 ; \bullet$, $I_{\text {Na-p }}$ active. No resonance could be observed in the model when $I_{\mathrm{Na-p}}, I_{\mathrm{K} \text {-slow }}$, and $I_{\mathrm{Na-r}}$ were turned off (thin dotted line). $C, I_{\mathrm{Na}-\mathrm{p}}, I_{\mathrm{K} \text {-slow }}$, and $I_{\mathrm{K} \text {-A }}$ at three different frequencies (thick line, $8 \mathrm{~Hz}$; thin line, $2 \mathrm{~Hz}$; broken line, $14 \mathrm{~Hz}$ ). Note the different frequency-dependent activation of these currents.
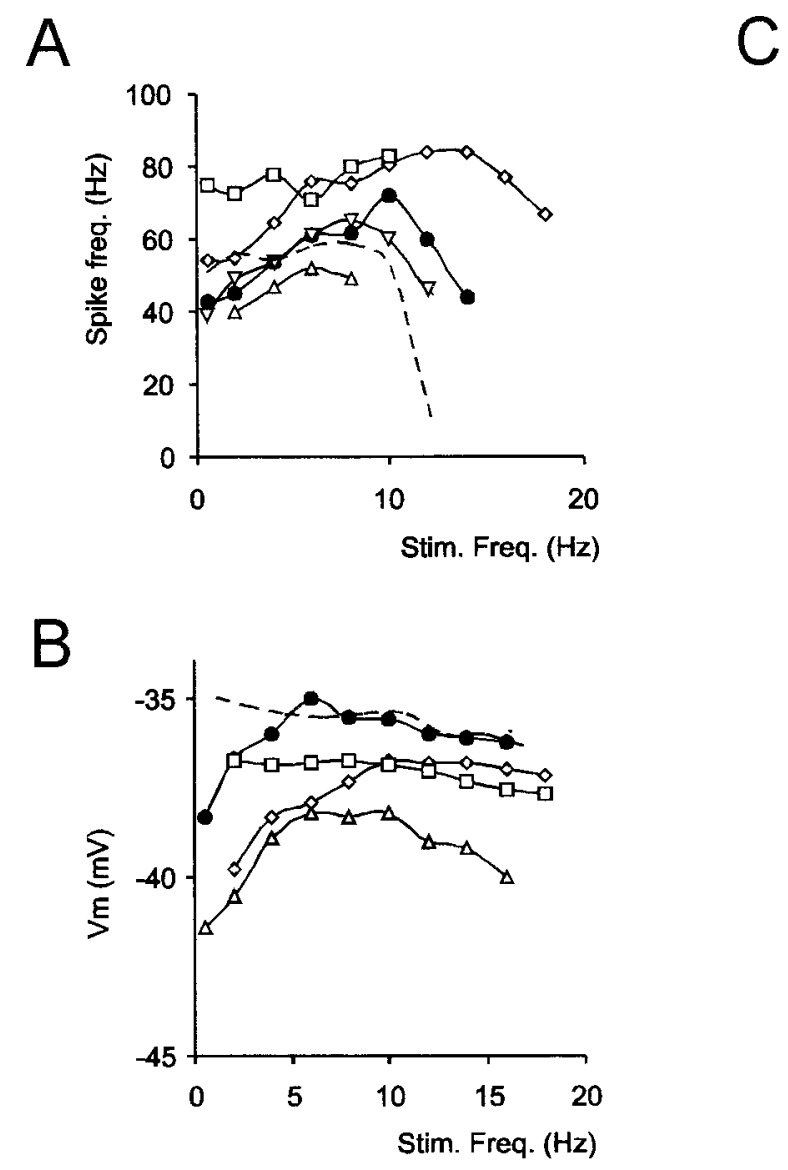
(Bardoni and Belluzzi, 1993), and $I_{\mathrm{K} \text {-slow }}$ (this study), (2) to identify different $\mathrm{Na}^{+}$current components (including $I_{\mathrm{Na}-\mathrm{f}}$, $I_{\mathrm{Na}-\mathrm{p}}$, and $I_{\mathrm{Na}-\mathrm{r}}$ ) (D'Angelo and Magistretti, unpublished results), and (3) to characterize the pharmacological properties of excitability (D'Angelo et al., 1998). Patch-clamp recordings from granule cells in culture were used to reconstruct $I_{\mathrm{K}-\mathrm{Ca}}$ (Fagni et al., 1991; Gabbiani et al., 1994). Although further investigation is required to clarify $\mathrm{Ca}^{2+}$ dynamics and the biophysical properties of the $\mathrm{Na}^{+}$current, mathematical modeling allowed us to investigate the role of $I_{\mathrm{Kslow}}$ in relationship to other excitable properties of the granule cell. In addition to modeling, $I_{\text {Kslow }}$ involvement in oscillations, bursting, and resonance may be investigated by $I_{\text {Kslow }}$ selective pharmacological blockage or by $I_{\mathrm{K} \text { slow }}$ electronic antagonism/expression through a dynamic-clamp circuit (Hutcheon et al., 1996a,b).

Experimental and modeling observations allow the following reconstruction of the ionic mechanisms of rat cerebellar granule cell electroresponsiveness.

(1) $I_{\mathrm{Na}-\mathrm{f}}$ and $I_{\mathrm{K}-\mathrm{V}}$ were the core of a fast oscillatory mechanism sustaining fast repetitive firing, as in the classical HodgkinHuxley model (Hodgkin and Huxley, 1952). $I_{\mathrm{K}-\mathrm{A}}$ increased spike latency (Connor and Stevens, 1971), and the $I_{\mathrm{Ca}}-I_{\mathrm{K}-\mathrm{Ca}}$ system stabilized repetitive firing by enhancing fast AHP and $\mathrm{Na}^{+}$ channel deinactivation [see also Gabbiani et al. (1994)].

(2) $I_{\mathrm{Na}-\mathrm{p}}$ and $I_{\mathrm{K} \text {-slow }}$ were the core of a slow oscillatory mechanism sustaining theta-frequency oscillation and bursting. $I_{\mathrm{Na}-\mathrm{p}}$ has been reported to sustain oscillations in association with $I_{\mathrm{M}}$ in neocortical pyramidal neurons (Gutfreund et al., 1995) and in association with $I_{\mathrm{h}}$ in enthorinal pyramidal neurons (Alonso and Llinas, 1989; Dickson et al., 2000). $I_{\mathrm{K} \text {-slow }}$ caused delayed repolarization, terminating the positive phase of the oscillation promoted by $I_{\text {Na-p. }}$.

(3) Emergence of bursting was regulated by the $I_{\mathrm{Ca}}-I_{\mathrm{K}-\mathrm{Ca}}$ system (D'Angelo et al., 1998) through the fast AHP, which reduced the depolarizing action of $I_{\mathrm{Na}-\mathrm{p}}$ (Azouz et al., 1996) and $I_{\text {Na-r }}$ (Raman and Bean, 1997) after the spike.

(4) Resonance depended on high-pass filtering caused by $I_{\mathrm{K} \text {-slow }}$ (generating the ascending branch of the resonance curve) in association with low-pass filtering caused by passive membrane properties (generating the descending branch of the resonance curve) and was amplified by $I_{\mathrm{Na}-\mathrm{p}}$. Thus, resonance involved subthreshold changes in membrane excitability [corresponding to subthreshold impedance resonance reported by Hutcheon et al. (1996a,b)], consistent with the identification of $I_{\mathrm{K} \text {-slow }}$ as a "resonator" current and $I_{\mathrm{Na}-\mathrm{p}}$ as an "amplifier" current" (Hutcheon and Yarom, 2000). In addition, the model suggested that $I_{\mathrm{K}-\mathrm{A}}$, which is inactivated at low but not high frequency, accelerated the descending branch of the resonance curve. Finally, the model predicted that resonance in burst spike frequency could be intensified by spike clustering promoted by $I_{\mathrm{Na}-\mathrm{r}}$. Thus, resonance and bursting may have in common their dependence on $I_{\mathrm{K} \text {-slow }}$ as well as that on $I_{\mathrm{Na}-\mathrm{r}}$.

Granule cells are excitatory interneurons relaying information conveyed by mossy fibers into the cerebellar cortex (Marr, 1969). Although repetitive firing implements a mechanism of linear frequency coding (Gabbiani et al., 1994), intrinsic bursting and resonance tune granule cells on theta-frequency, which is diff used in sensory-motor structures (Koch, 1999). Intrinsic bursting and resonance may favor granule cell phase-locking through the recurrent Golgi cell inhibitory circuit (Maex and DeShutter, 1998). Theta-frequency discharge has indeed been recorded from the granular layer during specific activity states in vivo (Pellerin and
Lamarre, 1997; Hartmann and Bower, 1998). Finally, as observed in the hippocampus (Holsher et al., 1997), theta-frequency bursting may regulate the induction of synaptic plasticity in the mossy fiber-granule cell pathway (D'Angelo et al., 1999; Armano et al., 2000).

\section{REFERENCES}

Adams PR, Brown DA, Constanti A (1982a) M-currents and other potassium currents in bullfrog sympathetic neurones. J Physiol (Lond) 330:537-572.

Adams PR, Brown DA, Constanti A (1982b) Pharmacological inhibition of the M-current. J Physiol (Lond) 332:223-262.

Alonso A, Llinas RR (1989) Subthreshold $\mathrm{Na}^{+}$-dependent theta-like rhythmicity in stellate cells of entorhinal cortex layer II. Nature 342:175-177.

Armano S, Rossi P, Taglietti V, D'Angelo E (2000) Long-term potentiation of intrinsic excitability at the mossy fiber-granule cell synapse of rat cerebellum. J Neurosci 20:5208-5216.

Azouz R, Jensen MS, Yaari Y (1996) Ionic basis of spike afterdepolarization and burst generation in adult rat hippocampal CA1 pyramidal cells. J Physiol (Lond) 492:211-223.

Bardoni R, Belluzzi O (1993) Kinetic study and numerical reconstruction of A-type current in granule cells of rat cerebellar slices. J Neurophysiol 69:2222-2231.

Brickley SG, Cull-Candy SG, Farrant M (1996) Development of a tonic form of synaptic inhibition in rat cerebellar granule cells resulting from persistent activation of $\mathrm{GABA}_{\mathrm{A}}$ receptors. J Physiol (Lond) 497:753-759.

Brown DA, Adams PR (1980) Muscarinic suppression of a novel voltage-sensitive $\mathrm{K}^{+}$current in a vertebrate neurone. Nature 283:673-676.

Connor JA, Stevens CF (1971) Predictions of repetitive firing behaviour from voltage-clamp data on an isolated neuron soma. J Physiol (Lond) 213:31-53.

Connors BW, Gutnick MJ (1990) Intrinsic firing patterns of diverse neocortical neurons. Trends Neurosci 13:99-104.

Cull-Candy SG, Marshall CG, Ogden D (1989) Voltage-activated membrane currents in rat cerebellar granule neurones. J Physiol (Lond) 414:179-199.

D'Angelo E, Rossi P, Taglietti V (1993) Different proportions of $N$-methyl-D-aspartate and non- $N$-methyl-D-aspartate receptor currents at the mossy fibre-granule cell synapse of developing rat cerebellum. Neuroscience 53:121-130.

D’Angelo E, De Filippi G, Rossi P, Taglietti V (1995) Synaptic excitation of individual rat cerebellar granule cells in situ: evidence for the role of NMDA receptors. J Physiol (Lond) 484:397-413.

D'Angelo E, De Filippi G, Rossi P, Taglietti V (1997) Synaptic activation of $\mathrm{Ca}^{2+}$ action potentials in immature rat cerebellar granule cells in situ. J Neurophysiol 78:1631-1642.

D'Angelo E, De Filippi G, Rossi P, Taglietti V (1998) Ionic mechanism of electroresponsiveness in cerebellar granule cells implicates the action of a persistent sodium current. J Neurophysiol 80:493-503.

D'Angelo E, Rossi P, Armano S, Taglietti V (1999) Evidence for NMDA and mGlu receptor-mediated long-term potentiation of mossy fibre-granule cell transmission in the rat cerebellum. J Neurophysiol 81:277-287.

DeSchutter E, Smolen P (1998) Calcium dynamics in large neuronal models. In: Methods in neuronal modeling (Koch C, Segev I, eds), pp 211-250. London: MIT Press.

Dickson CT, Magistretti J, Shalinsky MH, Fransen E, Hasselmo ME, Alonso A (2000) Properties and role of $\mathrm{I}_{\mathrm{h}}$ in the pacing of subthreshold oscillations in entorhinal cortex layer II neurons. J Neurophysiol 83:2562-2579.

Eccels JC, Ito M, Szentagothai J (1967) The cerebellum as a neuronal machine. Berlin: Springer.

Fagni L, Bossu J-L, Bockaert J (1991) Activation of a large conductance $\mathrm{Ca}^{2+}$-dependent $\mathrm{K}^{+}$channel by stimulation of glutamate phosphoinositide- coupled receptors in cultured cerebellar granule cells. Eur J Neurosci 3:778-789.

Gabbiani F, Midtgaard J, Knoepfel T (1994) Synaptic integration in a model of cerebellar granule cells. J Neurophysiol 72:999-1009.

Gutfreund Y, Yarom Y, Segev I (1995) Subthreshold oscillations and resonant frequency in guinea-pig cortical neurons: physiology and modeling. J Physiol (Lond) 483:621-640.

Hartmann MJ, Bower JM (1998) Oscillatory activity in cerebellar hemispheres on unrestrained rats. J Neurophysiol 80:1598-1604.

Hines ML, Carnevale NT (1997) The NEURON simulation environment. Neural Comput 15:1179-1209.

Hodgkin AL, Huxley AF (1952) A quantitative description of membrane currents and its application to conduction and excitation in nerve. J Physiol (Lond) 117:500-544.

Holsher C, Anwyl R, Rowan MJ (1997) Stimulation on the positive 
phase of hippocampal theta rhythm induces long-term potentiation that can be depotentiated by stimulation on the negative phase in area CA1 in vivo. J Neurosci 17:6470-6477.

Hutcheon B, Yarom Y (2000) Resonance, oscillation, and the intrinsic frequency preferences of neurons. Trends Neurosci 23:216-222.

Hutcheon B, Miura RM, Puil E (1996a) subthreshold membrane resonance in neocortical neurons. J Neurophysiol 6:683-697.

Hutcheon B, Miura RM, Puil E (1996b) Models of subthreshold membrane resonance in neocortical neurons. J Neurophysiol 6:698-714.

Irving AJ, Collingridge GL, Schoefield JG (1992) Glutamate and acetylcholine mobilize $\mathrm{Ca}^{2+}$ from the same intracellular pool in rat cerebellar granule cells using transduction mechanisms with different $\mathrm{Ca}^{2+}$ sensitivities. Cell Calcium 13:293-301.

Koch C (1999) Bursting cells. In: Biophysics of computation, pp 374380. Oxford: Oxford UP.

Llinas RR (1988) The intrinsic electrophysiological properties of mammalian central neurons: insights into central nervous system function. Science 242:1654-1664.

Maex R, DeSchutter E (1998) Synchronization of golgi and granule cell firing in a detailed network model of the cerebellar granule cell layer. J Neurophysiol 80:2521-2537.

Mainen ZF, Sejinowski TJ (1996) Influence of dendritic structure on firing pattern in model neocortical neurons. Nature 382:363-366.

Mainen ZF, Joerges J, Huguenard JR, Sejinowski TJ (1995) A model of spike initiation in neocortical pyramidal neurons. Nature 382:363-366.

Marchetti C, Amico C, Usai C (1995) Functional characterization of the effect of nimodipine on the calcium current in rat cerebellar granule cells. J Neurophysiol 73:1169-1180.

Marr D (1969) A theory of the cerebellar cortex. J Physiol (Lond) 202:437-470.

McCormick DA, Huguenard JR (1992) A model of the electrophysiological properties of thalamocortical relay neurons. J Neurophysiol 68: $1384-1400$.

Pape H-C, Driesang RB (1998) Ionic mechanisms of intrinsic oscillations in neurons of the basolateral amygdaloid complex. J Neurophysiol 79:217-226.

Pellerin P-P, Lamarre Y (1997) Local field potential oscillations in pri- mate cerebellar cortex during voluntary movement. J Neurophysiol 78:3502-3507.

Raman IM, Bean BP (1997) Resurgent sodium current and action potential formation in dissociated cerebellar Purkinje neurons. J Neurosci 17:4517-4526.

Rossi P, D’Angelo E, Magistretti J, Toselli M, Taglietti V (1994) Agedependent expression of high-voltage activated calcium currents during cerebellar granule cell development in situ. Pflügers Arch 429:107-116.

Rossi P, De Filippi G, Armano S, Taglietti V, D’Angelo E (1998) The weaver mutation causes a loss of inward rectifier current regulation in premigratory granule cells of the mice cerebellum. J Neurosci 18:35373547.

Silver RA, Traynelis S, Cull-Candy SG (1992) Rapid time course of miniature and evoked excitatory currents at cerebellar synapses in situ. Nature 355:163-166.

Tottene A, Moretti A, Pietrobon D (1996) Functional diversity of P-type and R-type calcium channels in rat cerebellar neurons. J Neurosci 16:6353-6363.

Traub RD, Llinas R (1979) Hippocampal pyramidal cells: significance of dendritic ionic conductances for neuronal functioning and epileptogenesis. J Neurophysiol 42:476-496.

Traub RD, Wong RKS, Miles R, Michelson H (1991) A model of a CA3 hippocampal pyramidal neuron incorporating voltage-clamp data on intrinsic conductances. J Neurophysiol 66:635-650.

Vanier MC, Bower JM (1999) A comparative survey of automated parameter-search methods for compartmental neural models. J Comp Neurosci 7:149-171.

Wang X-J, Rinzel J (1999) Oscillatory and bursting properties of neurons. In: The handbook of brain theory and neuronal networks (Arbib MA, ed), pp 686-691. London: MIT Press.

Watkins CS, Mathie A (1996) A non-inactivating $\mathrm{K}^{+}$current sensitive to muscarinic receptor activation in rat cultured cerebellar granule neurons. J Physiol (Lond) 491:401-412.

Yamada WM, Koch C, Adams PR (1998) Multiple channels and calcium dynamics. In: Methods in neuronal modeling (Koch C, Segev I, eds), pp 137-170. London: MIT. 